\title{
PEOPLE LIVING IN POVERTY WITH COMPANION PETS: BARRIERS TO ACCESS AND SUPPORT
}

\author{
by
}

Joey Violante, BSW, Ryerson University, 2018

\author{
An MRP \\ presented to Ryerson University \\ in partial fulfillment of the \\ requirements for the degree of \\ Master of Social Work \\ in the Program of \\ Social Work
}

Toronto, Ontario, Canada, 2019

(C) Joey Violante 2019 


\section{AUTHOR'S DECLARATION FOR ELECTRONIC SUBMISSION OF A MRP}

I hereby declare that I am the sole author of this MRP. This is a true copy of the MRP, including any required final revisions.

I authorize Ryerson University to lend this MRP to other institutions or individuals for the purpose of scholarly research

I further authorize Ryerson University to reproduce this MRP by photocopying or by other means, in total or in part, at the request of other institutions or individuals for the purpose of scholarly research.

I understand that my MRP may be made electronically available to the public. 


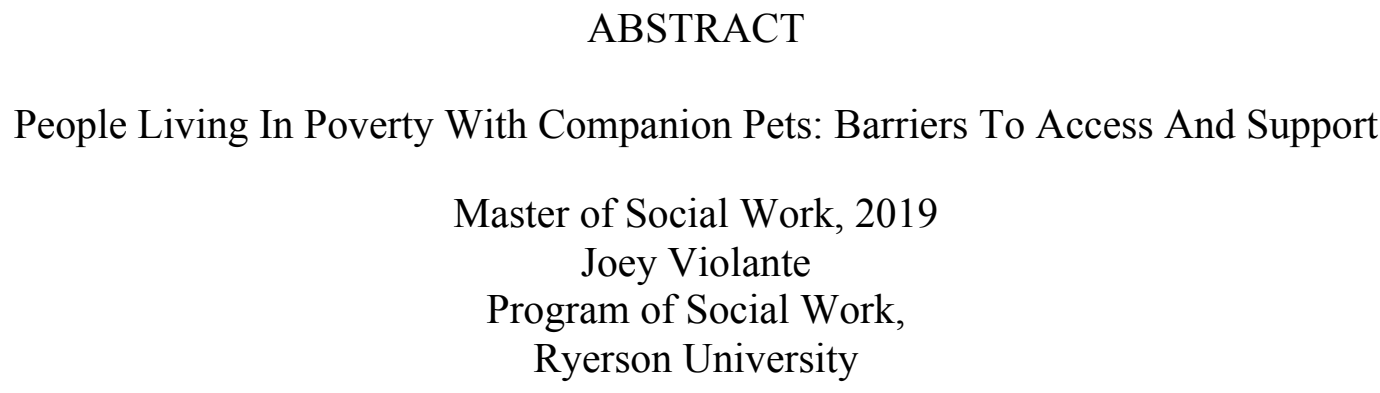

The purpose of this major research project was to make critical the experiences of people living in poverty and/or violent living situations with animal companions. I met with three participants; using qualitative semi-structured interviews, and a narrative approach. Participants highlighted issues of poverty, homelessness, gender-based violence and bounded choice in accessing services and supports. Using an intersectional feminist, post structural, and anti-oppressive analysis I explored the ideological and material barriers that impact women living in poverty with companion animals. This paper finishes with participants' recommendations for change and implications for social work. 


\section{ACKNOWLEDGEMENTS}

It took the support of so many people to make this possible; literally, every single person in my life.

To my parents who screamed with excitement when they learned I was accepted into this program and for never believing my school teachers who told you I would never make it to postsecondary. Thank you.

To my partner Mella, I cannot thank you enough for your unwavering support and care, for listening to me even when you were exhausted, and for just making me want to be a better human being every single day. Thank you.

Many thanks to my research supervisor Samantha Wehbi for your constant support and words of encouragement, and for keeping me on track!

And, a very special thank you to the participants of this research project. For your generosity in sharing your stories and wisdom with me, and your commitments to building a more equitable world, thank you. $<3$ 


\section{DEDICATION}

This paper is dedicated to an old friend whom I haven't seen in many years. I'm glad you and your sweet dog finally found a safe home, and I'm sorry this world didn't see you sooner. You probably don't even know it, but you changed me. Thank you. 


\section{TABLE OF CONTENTS}

CHAPTER 1. INTRODUCTION

THEORETICAL FRAMEWORK................................................................................................................................ 3

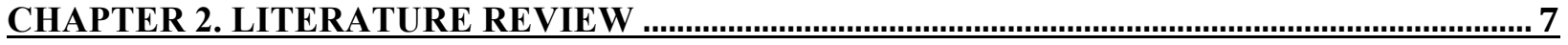

SEARCH STRATEGY................................................................................................................................................. 8

HUMAN-ANIMAL BOND /RELATIONSHIPS WITH ANIMALS ............................................................ 9

HOMELESSNESS AND PETS.............................................................................................................10

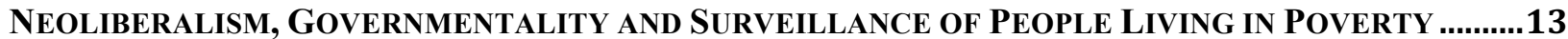

INTIMATE PARTNER VIOLENCE AND PETS................................................................................................14

DISENFRANCHISED GRIEF ...................................................................................................................15

Social Workers' Perceptions of Pets as Sources of ReCiprocal SuPPORT AND CARE........16

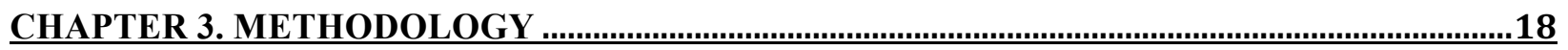

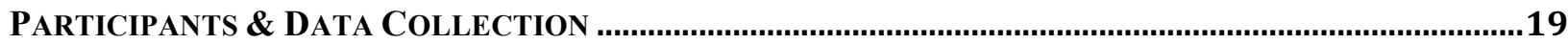

DATA ANALYSIS............................................................................................................................................. 19

ETHICAL CONSIDERATIONS .................................................................................................................. 21

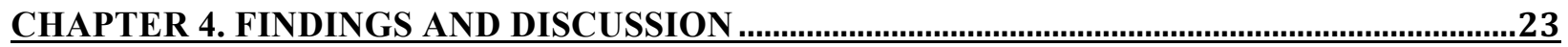

DOMINANT GENDERED EXPECTATIONS AND WOMEN AS CARERS ....................................................29

Dismantling OF THE Welfare STATE, NeOLIBERAL INDIVIDUALIZATION/THE NEOLIBERAL

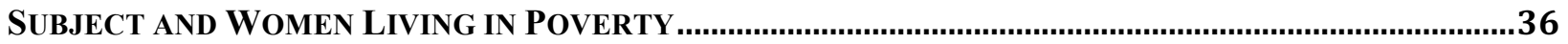

VIOLENCE: DUAL VIOLENCE AND GENDER-BASED VIOLENCE .........................................................44

CONCLUSION AND RELATIONSHIP BETWEEN THEMES ........................................................................49

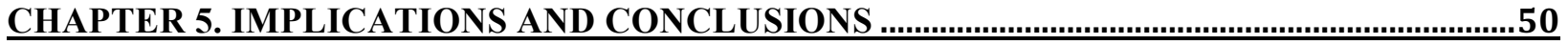

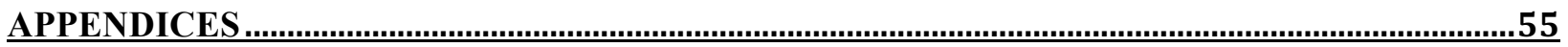

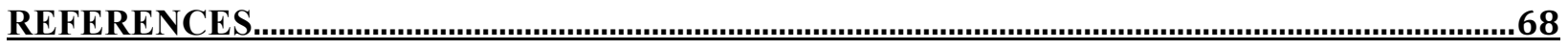


LIST OF APPENDICES

Appendix A-Consent Form

Page \# 55

Appendix B-Recruitment Flyer

Page \# 60

Appendix C- Email Recruitment Script

Page \# 61

Appendix D-Interview guide

Page \# 62

Appendix E- Facebook Notice

Page \# 64

Appendix F-Research Ethics Board Approval Document

Page \# 66 


\section{CHAPTER 1. INTRODUCTION}

Throughout my social work career, I have been working within the shelter system both with youth experiencing homelessness and with survivors of gender-based and intimate partner violence. Through these years I have heard recurring stories of the support service users have found in their companion animals, especially during difficult times in their lives, along with barriers which that bond has caused in accessing supports or in leaving a violent living situation.

Over the last year I have been involved in co-creating a grassroots non-profit made up of community members, community workers, and multiple volunteers who support with temporary care for low-income and marginalized individuals' companion animals in order to access services and later be reunited with their animal companion. By caring for a loved companion and recognizing this gap, we aim to validate service users' experiences of violence when choice is removed, thus caring for the person. This organization supports individuals living in poverty who are leaving and/or living in violent living situations, folks who are experiencing homelessness or are precariously housed, individuals who are criminalized or experience incarceration, psychiatric survivors, people in the mental health system, and individuals needing to access primary hospital care. Many people the organization has supported experience social isolation and poverty without options for pet care. This often leads to deciding between surrendering an animal companion in order to access support services, or forced pet loss to animal services due to oppressive systems of incarceration or involuntary mental health treatment. Based on these experiences and interests, the issue I will explore in this major research project is the ideological and discursively constructed 'validity' and 'legitimacy' of pets as a source of support for communities living in poverty, and the ways that this ideological framing of a social support creates barriers to accessing services and supports. 
This research explored the ways that these barriers are constructed and maintained by overarching ideologies of what supports are constructed as 'valid' and 'true' or 'legitimate' as well as who is discursively constructed as 'worthy' or 'deserving' of animal companionship. I aimed to center the voices of marginalized folks who have found a deep bond with an animal companion and explored the dual harm enacted through disenfranchised grief and violence that exists in the loss of, (or threat of loss of) a pet due to systemic and ideological barriers as well as the types of barriers that exist, and decisions that individuals are forced to make.

I know that in many ways this issue speaks to, and is a by-product of much larger systemic issues and oppressions such as; a lack of safe affordable housing, government and ideological priorities around liveable wages and poverty elimination, racism, colonialism, sexism, sanism, heterosexim and transphobia to name a few of the systemic structures and injustices that uphold this issue. I know that this research is a small step and starting point toward a larger conversation and ultimately toward systemic change. Ideally a support like the one described above may, one day, need not exist; but until that day I would like to remain committed to it being informed and guided by community.

I hope to build lasting relationships with participants and communities, by being critically reflexive of my role within the research and the power that operates within the research process. I am coming into the research as a university student and a researcher; a position of significant privilege. I am a white, queer, cis-genederd settler and though I have experiences of genderbased violence I have not experienced homelessness or the loss of a companion due to structural barriers or oppressions such as poverty, classism or racism. I would like to enter the research with these and other aspects of my subjectivity openly, understanding that in many ways I am an outsider to the communities who generously guided me in this process. 


\section{Theoretical Framework}

My understanding of this issue is complex and multi layered. The overall theoretical framework that is informing my understanding of this issue, and that has informed much of my work in this field is anti-oppressive theory. As described in Jeffery (2007), anti-oppressive social work is;

a form of social work practice which addresses social divisions and structural inequalities in the work that is done with 'clients' (users) or workers" (Dominelli, cited in Campbell, 2003). It does not represent a single or unitary perspective on social work practice, but rather includes a disparate and multidisciplinary variety of perspectives taken from feminist, radical, anti-racist, and other critical philosophies and social movements. (p.126)

Because anti-oppressive theories are multi-dimensional, my approach to anti-oppressive theory includes multiple frameworks and approaches. For the purposes of this MRP I will also be incorporating an intersectional feminist approach, and post-structural approaches which will be informed by anti-racism and critical race theories, decolonizing and anti-colonial approaches, queer theories and anti-capitalism.

\section{Intersectional Feminism}

Much of the scholarship that circulates in this area is in the context of gender-based intimate partner violence and pets; both as a source of support for survivors and a tool of coercion and control by abusers, along with the concern for care and wellbeing of a pet as a barrier to escaping violence. In Toronto, poverty is increasingly gendered and raced and women living in poverty have limited options when exiting a violent relationship or living situation. Without options for safe affordable housing, unliveable wages and a lack of adequate social supports women escaping violence are often forced into very precarious situations. With this in mind I hope to 
bring in an intersectional feminist perspective and problematize the social structures that uphold both intimate partner and gender-based violence as well as other forms of structural violence people living in poverty with pets may experience (Faver \& Strand, 2003).

Intersectional feminism and intersectionality, which has its roots in Black feminist thought, as discussed by Crenshaw (1991), looks to the ways racialized women's intersecting identities such as race and gender as well as other aspects of identity such as class, gender identity and sexual orientation, to name a few, interact with one another and within broader systems impacting experiences of racism, sexism, cissexim and poverty for example. As discussed by Khosla (2008), when looking at the ways women of colour experience poverty in Toronto the author notes;

Where poverty is discussed, it is portrayed as a largely generic, faceless phenomenon that falls randomly among the City's residents. This ignores the mounting evidence that systematic inequalities mean that women, people of colour and immigrants are the poorest Torontonians. For women of colour whose situation is compounded by multiple and intersecting disadvantages, the neglect escalates into absolute erasure. (p.7)

Issues of racism, sexism and poverty are compounded by racist hiring practices, a significant lack of safe affordable housing along with discrimination from racist landlords and discrimination against folks receiving social assistance, single parents, and the enforcement of 'no pet policies', to name a few (Khosla, 2008). All of this illustrates that poverty is not a random collection of 'hard luck', or being unable to 'pull oneself up by the bootstraps', as dominant discourses often imply, but, disproportionally affects marginalized communities (Khosla, 2008). Further, "the past ten years have seen significant rollbacks to equity programs [in Toronto] in many arenas. Free market dogma has overtaken public policy debate at all levels 
and those who fall to the bottom of the social order are blamed for their difficulties" (Khosla, 2008, p. 8).

\section{Post-Structural Approaches}

Because I will explore the ways that dominant discourses inform understandings about whose realities are dominantly constructed as 'valid' and 'true' and the ways that these understandings subjectively construct individuals' experiences, I believe post approaches to offer a strong framework (Healy, 2005). Through this, I will also explore the ways that neoliberal, colonialist, western knowledge informs the value and legitimacy of human animal bonds and the reciprocal relationships of care animals can facilitate.

Post theories challenge the notion that a single identifiable, fixed 'truth' exists. Rather, they argue that meaning is contextually and socially constructed, always in flux and shaped by the discourses that are available to us (Healy, 2005). As discussed by Healy (2005), "post [theorists] focus on understanding local details and complexities, such as the diverse experiences of people within a community, rather than trying to construct a single story or narrative about an event or population" (p.196). Four key concepts in post theories include: discourse, subjectivity, power and deconstruction. Discourse, refers to the way language constructs what is dominantly understood as 'true' knowledge and whose knowledges are prioritized and given legitimacy (Healy, 2005). In this MRP I will look to the ways particular discourses compete, and the ways that dominant, harmful, discourses are granted legitimacy and power as I work to centre marginalized discourses.

Other important concepts within post-structural theory are around power and the often hidden in relational ways that power operates; not through force, but through the everyday discourses and ideologies that uphold it. As discussed by Moffatt (1999) about the surveillance of people 
living in poverty accessing social assistance for example, the construction of people living in poverty and creation of the "welfare cheat" creates social conditions in which people are scrutinized and surveilled through being constructed as "a grave risk to the morality of the social body" (p. 242).

Surveillance and visibility go beyond what is imposed by government within social assistance offices and into societal ideologies creating conditions where people living in poverty are scrutinized for what supports are considered 'valid' and worthy of social welfare funds for example, as well as how money is spent on supports (Moffatt, 1999). These concepts of surveillance are deepened by another Foucauldian concept of governmentality. Governmentality, not referring necessarily to the ways that neoliberal governments enforce ideology around what constitutes the 'ideal citizen', or legitimate knowledge, but rather, the act of governing which can include the ways we govern one another, and self-govern through the internalization and enforcement of these dominant neoliberal ideologies (Foucault, Senellart, \& Burchell, 2008).

Taking these theoretical perspectives into account, the MRP will explore dominant neoliberal ideologies that contribute to who is discursively constructed as the 'ideal' neoliberal subject and the ways that these dominant norms work to marginalize people living in poverty, and uphold multiple systems of oppression. Using these theoretical perspectives, including intersectional feminism and post theories I will explore the ways that intersecting and interlocking sites and systems of privilege and oppression work in tandem with neoliberal ideologies. What follows is a discussion of the main themes from the literature regarding people living in poverty with pets. 


\section{CHAPTER 2. LITERATURE REVIEW}

Because there is little critical social work literature that relates directly to this issue, I have used a multidisciplinary approach in seeking scholarship (still much of which is not critical which I will discuss in further detail). The main themes that have emerged through my literature search are: human animal bond, homelessness and pets, issues around poverty, neoliberalism, governmentality and surveillance of people living in poverty (related to the dominant discourses to be explored), intimate partner violence and pets, disenfranchised grief and social workers perceptions on pets and sources of support and care. I was able to find some research that spoke to people living in poverty and experiencing homelessness with pets; however, I have found little of the research approaches the issue critically or looks to the multiple systems of marginalization that uphold this issue.

Multiple disciplines have contributed to this knowledge using various epistemologies and within each, the approach to the topic varies as well as who is considered a 'knower'. For example, much of the research I have encountered on the topic of people living in poverty with companion animals focuses on the companion animal before marginalized communities and frames the research often individually, either in terms of individual benefit of companion animals or individualized 'interventions' (Cronley, Strand, Patterson, \& Gwaltney, 2009; Risley-Curtiss, 2010; Slatter, Lloyd, \& King, 2012). Few studies but one tie in capitalism, issues around poverty and poverty elimination, neoliberalism, issues around surveillance of people living in poverty or anti-colonialism (Boyd, Cunningham, Anderson, \& Kerr, 2016).

Dominant biomedical, positivist approaches are situated in Eurocentric dominant knowledge's that value 'rationality', and western universal knowledge's while subjugating marginalized knowledges. Issues such as who owns the knowledge, and the long-term relationship and impact 
on the community are excluded in much of this process (Maiter, Simich, Jacobson, \& Wise, 2008).

The field of veterinary science seems to be a strong contributor to the knowledge on this issue as well as occupational therapy, clinical social work (when looking at human-animal bond), and sociology. And though many of the research studies I have reviewed have interviewed people who experience homelessness, and discuss the barriers folks might experience in caring for or losing a companion animal, as well as the 'choices' individuals must make, the way these stories are framed are rarely situated within the broader social contexts described above. Much of the research I have found in this area has come from positivist, western, evidence- based or medical frameworks with researchers seeking a singular truth, marginalizing the rich knowledges of people living in poverty (Gray, Plath, \& Webb, 2009).

\section{Search Strategy}

Through my initial search, it was challenging to find scholarship or research directly related to this issue. However, through online searches of peer reviewed scholarship and exploring sources that other authors used, I was able to find some related material. However, information from social work journals that focused on the social justice issues surrounding people with pets living in poverty seemed non-existent.

I have looked to multiple online databases for scholarly articles as well as broader online resources and books. I have searched the online Ryerson University Library and Archives social work abstracts, social service and sociology abstracts as well as broad searches using various key words to find interdisciplinary sources. Some of the key search terms included poverty and pets/animal companions, poverty and surveillance, governmentality, homelessness and pets, social work and pets/companion animals, human-animal bond and poverty among others. 


\section{Human-Animal Bond /Relationships with Animals}

Human-animal bond has been studied in various forms. Much of the research in this area tends to focus on physiological responses/benefits and takes a positivist, evidence-based or medical approach to the issue and the research (Gray et al., 2009). Much of the scholarship I reviewed framed this issue often individually and did not tie it to larger social structures or issues of marginalization in the lives of animal caregivers living in poverty. For example, Walsh (2009), discusses the way pets support health by lowering blood pressure, boosting human immune systems, and have been shown to aid in coping with chronic conditions such as heart disease, dementia and cancer (Walsh, 2009).

Lem, Coe, Haley, Stone, and O'Grady (2016) conducted a quantitative study, surveying 190 youth who experience homelessness using biomedical and evidence-based approaches/theories, such as depression scales, to find associations between homelessness, pets and depression. The authors cite that pets for young people experiencing homelessness provided a source of unconditional emotional support and protection, and eased loneliness. However, due to barriers within shelters and other social services with 'no pet' policies, youth often experienced barriers in accessing support (Lem et al., 2016). The researchers connect the issue to some structural issues within the shelter system but in the end do not discuss critical issues related to marginalization and oppression in the lives of youth experiencing homelessness. For example, the authors connect caring for a pet with decreased depression and discuss the prevalence of depression that youth participants described, but did not discuss the social contexts impacting mental health or poverty such as racism, sexism, homophobia, transphobia or other structural oppressions that impact and uphold these issues (Lem et al., 2016). 
Other research that looked at human-animal bond took a less biomedical approach, and used qualitative approaches, but still did not tie in critical issues. For example, as described by Yamasaki (2018), pets in a long-term care setting facilitated communication by acting as a social buffer fostering healing and providing alternative ways of knowing for their guardian. The author also explored the way companion animals facilitate meaningful communication within a hospital setting for folks living with chronic or terminal illness. The author uses semi-structured interviews and observation to understand the socially constructed meaning of human-animal relationships in the service setting (and applies these findings to improving the services, which has a pragmatic element as well) (Yamasaki, 2018). However, the author does not identify a value position, but rather interprets the meaning of the interactions without interrogating the social context, or social conditions that are impacting participants' experiences or the research relationship (Neuman, 2006; Yamasaki, 2018).

Other sources that discussed the benefits of human-animal bond include research by Kabel, Khosla, and Teti (2015), who discuss companionship, unconditional love, routine, pets' capacity to support in easing social isolation and providing a source of nonjudgmental support. In other scholarship, for women experiencing homelessness, pets played a significant role in supporting a sense of safety, responsibility, routine, companionship and provided therapeutic support (Hardesty, Khaw, Ridgway, Weber, \& Miles, 2013; Labrecque \& Walsh, 2011).

\section{Homelessness and Pets}

Another theme, though scarce in terms of critical research, is around people who experience homelessness with animal companions. For example, an ethnographic research study by Irvine (2016), conducts qualitative interviews with participants experiencing homelessness with an 
animal companion. The participants describe the stigma they experience; often being questioned about the welfare of their pet. And, as discussed by Irvine, Kahl, and Smith (2012),

"On one hand, interactions with the public can result in gestures of goodwill, such as a contribution of pet food, $[\ldots]$. On the other hand, interactions can also mean confrontation: an attack on the homeless person's character in which he or she is deemed unable to care for the animal, and therefore undeserving of animal companionship". (para.7)

Further, the sociological research by Irvive (2016), though a contribution to an otherwise scant conversation, was somewhat lacking in making critical the issue, and instead much of the focus and findings tended toward individualized notions of self in relation to an animal companion, sometimes decentring people living in poverty. Irvine (2016), looks at identity, the concept of home, and the benefits and challenges that people who experience homelessness with pets' experience. However, the research, though ethnographic, where the researcher conducts qualitative interviews with participants, uses othering and distancing language, which decentres marginalized communities as the knowers.

Howe and Easterbrook (2018) discuss the costs and benefits of pet ownership for people experiencing homelessness; pet ownership caused barriers in accessing support services and also had many benefits for pet guardians such as companionship and increased resilience. Similar findings around barriers to support for people living in poverty with pets also emerged in the research as well as themes around a lack of choice in seeking support, placing many in a precarious position of staying with a pet or seeking housing support, or delaying the decision to leave an abusive living situation (Cronley et al., 2009; Hardesty et al., 2013; Howe \& Easterbrook, 2018; Labrecque \& Walsh, 2011; Lem et al., 2016; Slatter et al., 2012) 
Lem et al. (2016), conducted participatory action research and recruited youth experiencing homelessness to support with, and inform multiple aspects of the research. While this research may have critical elements, I believe that the methods and data analysis are more positivist because the research findings focus on causality and determinism by attempting to find a single reality about the connection between depression, pets and homelessness (Lem et. al, 2016).

In the research by Slatter et al., (2012), the researchers use semi-structured interviews to explore the barriers that people with pets who are experiencing homelessness face by highlighting the complex experiences of people living in poverty (Slatter et al., 2012). Though the researchers seek rich description of participants' experiences, when it comes to data analysis the researchers individualize participants experiences of poverty and homelessness, situating the research within the discipline of occupational therapy. Instead of using critical theories that challenge the social structures that perpetuate and uphold poverty, racism, classism, neoliberalism and sanism, the researchers use family and attachment theories that individualize these social issues and call for individual responses to these issues, as opposed to a calling for social action and change (Hunter, 2002; Neuman, 2006).

Finally, research by Labrecque and Walsh (2011), is situated within a feminist and critical paradigm, but also has pragmatic elements in that the findings look at changing shelter services, but also call for broader social change and the disruption of power structures. The researchers interview women experiencing homelessness within a shelter environment with companion animals. The researchers conduct in-depth interviews using a phenomenological approach and instead of focusing solely on demographic variables, like many of the other research studies I reviewed, the researchers focused on the multiple intersecting subject positions of the participants (Smith, 2017). Further, the authors situate the research within critical theories such 
as the feminization of poverty and raise consciousness around issues of gender-based violence and power relations both currently and historically in the lives of women experiencing homelessness (Labrecque \& Walsh, 2011; Neuman, 2006). This research discusses the barriers to participation in the study and indicates whose voices have been left out of the research when interviewing women experiencing homelessness. In this study the researchers create vignettes of individuals stories without over-interpreting; this indicates that the researchers wanted to centre the voices of women directly impacted as the knowers (Labrecque \& Walsh, 2011).

\section{Neoliberalism, Governmentality and Surveillance of People Living in Poverty}

Another theme centres on surveillance of people living in poverty and the individualizing of social issues. As discussed by Boyd et al., (2016) in their research of supportive housing and surveillance, people living in poverty are subject to social control through over policing, and other modes of regulation. Similarly, Bullen (2015) discusses the ways that 'welfare reform' increasingly focuses on individualized issues around self-reliance shifting away from structural issues that uphold poverty and marginalization.

As discussed by Moffatt (1999) about the surveillance of people living in poverty accessing social assistance, the construction of people living in poverty and creation of the "welfare cheat" create social conditions in which people are scrutinized and surveilled through being constructed as "a grave risk to the morality of the social body" (p. 242). Surveillance and visibility go beyond what is imposed by government within social assistance offices and into societal ideologies creating conditions where people living in poverty are scrutinized for what supports are considered 'valid' and worthy of social welfare funds, as well as how money is spent on supports (Moffatt, 1999).

Some of the research that looked to surveillance and control of marginalized bodies and of 
people living in poverty used more critical theoretical frameworks that interrogate power and social structures that uphold oppression as well as call for action (Neuman, 2006; Bullen, 2015). Bullen (2015), for example, looks at neoliberal ideology and policy that individualizes social issues and upholds poverty and homelessness. The author calls for action in the form of changing 'charity models' that individualize and construct folks as 'dependent' to addressing social structures that hold these ideologies in place. In addition to this, these critical epistemologies that also look at the historical context of oppression, take a strong axiological value stance seeing that no knowledge is neutral (Carter \& Little, 2007; Neuman, 2006).

\section{Intimate Partner Violence and Pets}

Multiple barriers to support are described in the scholarship around intimate partner violence (IPV) and pets. As discussed by Hardesty et al., (2013), 40\%- 92\% of IPV shelter clients care for pets and the level of attachment or bond to that pet was related to the level to which the pet was used as a tool of control by the abuser. Because most shelters do not allow animals, the fear of the pet being harmed if left behind, delayed many women's decision to leave an abusive relationship (Faver \& Strand, 2003; Hadesty et al, 2013). In addition to this, when women had to relinquish their pet in order to leave the abusive relationship, many identified a loss of a significant source of support (Hardesty et al., 2013). As discussed by Hardesty et al:

Women must weigh a myriad of factors when deciding to leave, including children, finances, and their physical and emotional health (Faver \& Strand, 2003). It is important to give women permission to be concerned about their pets. When their concerns are centered on themselves and their children, women may worry that their concerns about their pets are not legitimate. (Hardesty et al, 2013, p. 2634) 


\section{Disenfranchised Grief}

A theme that emerged in the majority of the scholarship I searched is around grief and loss. As discussed above, when the legitimacy of a source of support is ignored, or discursively constructed as not valid, grief associated with the loss of a pet due to structural violence becomes disenfranchised or is minimized (Donohue, 2005). Additionally, many of the research findings explored themes that participants discussed around loss of a source of support from a pet due to a lack of choice and understanding by services with which they came into contact (Hardesty et al., 2013; Howe \& Easterbrook, 2018; Labrecque \& Walsh, 2011; Slatter et al., 2012).

As discussed by Donohue (2005),

the resolution of grief by bereaved pet 'owners' may be compounded by the absence of universally accepted social standards for mourning a companion animal. Consequently, pet 'owners'[quotations added] struggling with loss may not receive adequate [...] support [...], and may feel alone and reluctant to share their feelings. (para.9)

As similarly described by Duffey (2007), pet loss is often socially disenfranchised, leading service providers to minimize the loss, further isolating individuals in their grief.

I will not focus on pet loss due to death alone, but rather loss (or threat of loss) through separation due to structural barriers and dominant discourses. I will explore how grief becomes further disenfranchised when individuals living in poverty with pets are discursively constructed as being 'unfit' pet caregivers due to being viewed as unable to provide for a pet financially or socially because of the visibility and surveillance of people living in poverty (Moffatt, 1999). This is combined with neoliberal, capitalist, colonial ideology and discourses that individualize experience and frame pets (and many animals more generally) as material property, as opposed to beings that we are in relationship with. 


\section{Social Workers' Perceptions of Pets as Sources of Reciprocal Support and Care}

Finally, though there was little critical social work research on this issue, I was able to identify research that spoke to the way social workers may include pets in practice (unfortunately this did not speak to marginalized folks living in poverty with pets). Risley-Curtiss (2010), found in a quantitative study of 5,012 NASW members that although the majority of social workers surveyed were aware of the impact of human-animal bonds, few participants used this in practice.

Risley-Curtiss (2010), also uses a positivist epistemology through quantitative research. The authors survey social workers on human-animal bond and positions social workers with particular levels of educational attainment as knowers, seeking who they describe as 'experts' in the field of human-animal bond to create the survey questions. The researchers use dichotomous and binary demographic categories and explicitly seek generalizable knowledge on the topic even though the researchers indicate the lack of racial and educational diversity of participants stating that $80 \%$ of the 1,649 participants were white and $95.7 \%$ held an MSW (Risley-Curtiss, 2010). Overall the researchers focused on social workers with high levels of education, who were upper middle class and predominantly white, indicating that white western social work may be framed as the 'expert' on this topic (Risley-Curtiss, 2010).

\section{Gaps \& Research Questions}

As previously discussed, there is a paucity of research that looks directly at social structures of marginalization or discursive features that uphold issues of poverty and relationships with companion animals. When linking together multidisciplinary research on the issue, multiple epistemological themes emerged. There are many gaps that exist in the literature in terms of critical anti-oppressive literature that centres the experiences of people living in poverty with 
pets within the current and historical social context. Because of this, I plan to bring in additional literature that centres the broader social issues of marginalization. Hence, my proposed research questions based on the existing literature and gaps would be: what barriers exist for people living in poverty with pets in accessing support or services? How is the 'validity' of pets as a source of support for communities living in poverty discursively created/constructed? 


\section{CHAPTER 3. METHODOLOGY}

A critical narrative methodology using semi-structured interviews was selected as a means to highlight the diverse experiences of participants through storytelling. With this in mind, as discussed by Chase (2003), narratives; the stories we tell about ourselves and the stories that others tell about us, are situated within dominant discourses that shape our understandings of the world and the ways that the we are understood. In other words, none of us are an island unto ourselves, but are in constant conversation with broader discourses. In this sense, a narrative approach is a conversation both within the context of, and with larger social structures. Additionally, as discussed by Chase (2003), the stories that we tell about our experiences have meaning "most researchers who conduct in-depth interviews are interested in the meanings people construct as they talk about their lives, as well as in the social contexts and resources that enable and constrain those meanings" (p.81). My hope is that this methodology will lend well to the theoretical approaches I will take. Post-modern and post-structural theories often focus on discourse, and the ways that dominant discourses and the stories we tell about ourselves, or that others tell about us, shape our realities and experiences (Healy, 2005).

The goal of the research is to fill a gap in understanding by framing the issue of people living in poverty with companion animals from a social justice/critical lens as much of the research in this area has taken a positivist or individualized approach that does not explore the social conditions or has alternatively taken a quantitative approach, which does not centre the rich knowledges of individuals living in poverty who identify a bond with a companion animal. I would like to take a critical narrative approach by holding space for co-creating counter narratives that challenge the dominant narratives marginalized communities are too often subject to. 


\section{Participants \& Data Collection}

For this major research project, I conducted semi-structured qualitative interviews with three participants over the age of 18 living in the Greater Toronto Area. Participants self-identified as living in poverty, experiencing housing insecurity or homelessness, living in or exiting or have exited a violent living situation (in whatever way that is defined by the participant). Participants were also currently caring for, or have in the past cared for a pet (cat or dog) with whom they identify as having a bond, and have accessed or wished to access social service supports such as housing support, shelters, mental health supports and others, or be in contact with systems involuntarily such as mental health systems and the criminal justice system. Participants selfidentified as having experienced barriers to access due to a pet or loss of a pet due to these barriers and/or imposed systems.

The data collection method that I used is critical narrative storytelling through recorded semistructured interviews of approximately one hour in length. During the interview process I took note of the way participants spoke to their experience including body language, pauses, facial expression and tone, all of which may provide clues about the process of meaning-making (Chase, 2003; Fraser, 2004).

\section{Data Analysis}

As discussed by Smith (2017), while reflecting on qualitative research participants' narratives and working with the whole; situating participants' stories based on fixed identity markers alone can miss the intricacies of lived experience and the nuance and complexities that may shape participants experiences. As Smith (2017), writes: "when reading through my transcripts, I was struck by how my participants' lives literally spilled over the edges of these ready-made categories" (p.80). Smith goes on to write: "participants accounts of themselves revealed 
complicated intersections, fluidities, overlappings, and inconsistencies that cannot be contained within the simplistic and predetermined categories of identity" (p.80).

Pen portraits, as described by Hollway \& Jefferson (2000), aim to 'work with the whole' by providing a rich introduction to each participant that that does not "iron out inconsistencies, contradictions and puzzles" or the ways that multiple identities and experiences may bump up against one another, contradict or intersect (p.14).

The pen portrait aim[s] to write something [that makes] the person come alive for a reader. [...]. In a way, a pen portrait serves as a substitute 'whole' for a reader who will not have access to the raw data but who needs to have a grasp of the person [...] if anything said about him or her is going to be meaningful. (Hollway \& Jefferson, 2000, p.14)

For this MRP it is important to me to work with the whole of participants' stories as much as possible as I ask myself; "who owns the story? Who can tell it? Who can change it? Whose version is convincing? What happens when narratives compete?” (Creswell 2013, p.76). And though I know that the research process is a co-construction between myself as the researcher and participants, and that particular aspects of participant stories may remain salient to me where others are missed due to my own subject position, I feel that providing the context of the whole is an important starting point that acknowledges the complexities and messiness of lived experience as well as a foundation for exploring the various themes in participant stories.

In terms of data analysis, I used an inductive, ground up approach which started from the data collection stage, meaning that interviews were semi-structured giving space for participants to share their stories as they saw most fit. I transcribed the recorded interviews and analyzed data using thematic analysis. I did this by reviewing the transcribed interviews multiple times and assigning codes to each meaning unit, first going through each interview separately and creating codes as new meaning units came up and then reviewing all transcripts again to apply any new 
relevant codes. From there I grouped codes to create categories of broader experience that seemed related or relevant to one another to arrive at broad categories or discourses (Chase, 2003). Finally, I analyzed the ways that the categories related, to or were in communication with one another to arrive at main themes.

In each step of the process I aimed to use a ground up, inductive approach to data analysis. I did not use the interview questions as a guide to create codes, nor did I base the data analysis on my literature review as the literature review was conducted based on my own biases and understanding of the issue, not participants. However, I would like to remain mindful that through this process, the ways that I guided interviews, coded, and analyzed the data were from my own subject position and framed within my own experiences and worldviews; this means that codes, categories and ultimately themes did not simply appear or emerge from the data but rather were a co-construction through my own interpretive process. As has been discussed previously, no research is neutral; my own value position, biases and worldview significantly impacted every aspect of this process. For example, the choice of particular codes over others, the systematic use and application of those codes, and ultimately the themes that were derived from those codes and categories, were my own interpretation of what aspects, words or experiences seemed significant. And though I did my best to stay as close to the data as possible when arriving at codes and categories, to remain as true to participants' experiences and stories as possible, no aspect of this process was neutral or value free.

\section{Ethical Considerations}

There are multiple ethical considerations within this research process. First, there are many gaps that exist in the literature in terms of critical anti-oppressive research on this issue that centres the experiences of people living in poverty with pets within the current and historical 
social context. Because of this, I plan to bring in literature that ties in the broader social issues of marginalization on this issue. In terms of the research process, I understand that reciprocity in terms of building long-term relationships with community is difficult during this short MRP process. However, because as I discussed earlier, I am currently involved with a grassroots nonprofit support that centres the experiences of people living in poverty and living in or leaving violent living situations who care for pets, I hope to continue to build reciprocal relationships with participants in this way by centring community members in guiding this support through ongoing collaboration and through remaining accountable to the community.

I would like to remain critically reflexive throughout each step of the research process, from using methodologies like critical narrative inquiry and co-constructing counter stories, centring marginalized stories and experiences, and doing so in the way that the community would like them to be told. 


\section{CHAPTER 4. FINDINGS AND DISCUSSION}

In this chapter I will highlight and explore qualitative interviews with three participants of this research project. Participants all identified as living in poverty, and caring for or previously caring for an animal companion that each described a unique bond with. Though I did not set out to recruit women specifically for this study, it is important to note that all three participants I met with were women, and the overwhelming majority of interested participants for this research also identified as women; an element of identity that shaped my analysis significantly and, as will be

presented, participants identified as playing a significant role in their experiences.

Two of the three participants identified that they were mothers, and all three participated in caring work to various degrees. It is also important to highlight that although it was not a qualifying criterion, all three participants participated in social justice work, most to a significant extent; an element I feel to not be coincidence. Two participants described social justice work as quite central to their identity and playing a significant role in their lives, volunteering their time and resources for decades. Another important piece that was consistent across all three interviews was in regards to how participants' beloved animals came into their lives; all animals were/are rescue animals, or animals that would have ended up in the shelter system or as some participants highlight, potentially euthanized.

Each participant described unique experiences and lived realities of poverty, surveillance, gender-based violence and dehumanization, and simultaneously all three speak to resilience and sharing their experiences to challenge the systemic and ideological structures that uphold poverty, gender-based violence, sanism, ableism and marginalization. Two of the participants I met with experience/d homelessness and one participant's story centres around her experience of 
surviving gender-based intimate partner violence, poverty and dual violence, where her relationship with her beloved cat at the time was concerned.

In terms of elements of identity that participants identified as impacting their experiences, the most salient aspects were gender and class for all three participants as well as mental health, sanism and ableism for two of the participants. Though race, and white privilege would impact participants experiences, this was not salient in participant interviews. However, as was previously discussed, race and racism significantly impact women living in poverty, and using an intersectional feminist analysis this will be discussed in the discussion section of this chapter. In the interest of working with the whole of participants' stories, experiences and subjectivities as much as possible, I would like to begin this chapter with a pen portrait to highlight the complexity of participants lived realities (Hollway \& Jefferson, 2000).

\section{Noreen}

Noreen and I met over the phone. Noreen is in her 50's, and describes herself as disabled, usually walking with a cane, and says that though she is familiar with challenges getting around, a recent injury has increased these challenges for her. Noreen is a mother, identifies as bisexual and notes that she is currently partnered with a male partner. Noreen reflects on some complication around race, and particularly Indigeneity. Though Noreen identifies as white and as having white privilege, and says that she was "raised with all the privileges afforded to a white girl child" she notes that this is a hard question to answer because she is unsure of her heritage.

Noreen reflects on the past and also talks about the present in our interview. Telling stories about surviving a very violent relationship and the role her cat at the time played in her life and how nice it was to get to talk about him again since it has been many years. Noreen currently lives with her three cats, is on ODSP and identifies as poor: 
I would consider myself poor, I'm unemployed I'm currently on ODSP, umm so that's pretty limiting for me but on the other hand it allows me time and energy to do the work that I do, what I consider my work I'm a rape crisis counselor (Noreen)

Noreen's voice is filled with energy when she tells me about her work: "yeah that's part of who I am a $B I G$ part of who I am I've been doing that for almost 30 years now. Noreen describes her current cats as everything to her; they are her family and all three of them rescues that had been dumped on a university campus where Noreen attended school. And one cat, that Noreen cared for many years ago and who was the centre of many of her stories, was a rescue as well.

This cat was kind of special to me at the time because umm .. (long pause).. we are going back a long time but uh at the time I was in quite the abusive relationship so the cat was extra special to me. Um, at times was a source of support and um really was a smart cat because it was targeted because it was something I loved (Noreen)

\section{Natalie}

Natalie is a white woman in her mid-forties who identifies as living in poverty and experiencing mostly invisible homelessness. Natalie describes the last several years as being extremely precarious where she has moved to various motels, sometimes stayed with friends and acquaintances and sometimes stayed outside. When Natalie and I met she expressed the precariousness she is experiencing in housing and employment. She has been working multiple precarious, minimum wage jobs often everyday of the week to pay for her motel room where she lives with her husband and her dog. I offered to meet Natalie over the phone (she has a long commute to work most days) to save her another trip on her time off, but she insisted we meet in person expressing how important it was for her to make time to advocate for social change. 
Natalie says that her dog has been one of the most important parts of her life while she reflects on meeting her current husband, addiction, raising her children as a single mom and surviving gender-based violence:

yeah she, she has been probably been one of the most important parts of my life. I umm I moved through years ago, moved through addiction, I've been clean for a lot of years 13 years and I kind of really did the best I could to have a normal life it really was centered around my children and rebuilding our lives and going to school and just finding new ways to build on and improve that life. I met my husband almost 9 years ago and we just clicked and he quickly, you know just, things just moved really fast but it was a really positive relationship where we really supported each other, it was probably my first non-toxic relationship (Natalie)

Being a mother is also an important aspect of identity for Natalie, she often talks of the way her and her children support one another, and reflects on what it is like for her have been a young mom and the judgments that exist around that.

I was an extremely, extremely young mother so my daughters' friends now most of their mothers are about $15-20$ years older than me so for my 22 year old particularly she said now that I think about it I get really freaked out because when I tell people how old you are they are like "what? She's a baby" she's like "no she's my mother and she's that age" so yeah it is kind of weird (Natalie)

Natalie takes me through the chronology of the precariousness of the past several years starting with a serious house fire and followed by a string of "bad/failed tenancies" and unfair evictions, culminating in her husband suffering a stress-induced heart attack and being fired from his employment. Natalie reflects on often being called "selfish", this word came up multiple 
times in our interview; so much so that Natalie says it echoes, for trying to keep her family together through poverty and extreme precariousness, her family including her beloved dog of many years. Natalie describes that caring for her dog, along with multiple barriers to safe affordable housing has meant no access to shelters, and some very difficult decisions.

\section{Kathy}

Kathy is a white woman who is in her late 60 's and identifies as living in poverty for much of her life. Kathy was homeless for almost 30 years, she came to Toronto when she was 13 to live with her grandmother and left home soon after, experiencing precarious employment and homelessness. Kathy tells me that she completed school up to grade 2, and reflects on becoming homeless after being fired from a job because she could not read or write:

my grandmother said you have to pay room and board to stay here so I walked from Broadview and Queen where I lived, down to Bathurst and Queen, got a job at a shoe store but because I couldn't read or write I couldn't find the shoes and got fired (laughs). So, I went from job to job being homeless, going to shelters. I went to a detox centre and that's the place they put me because they didn't have room any place else. So, they kept shifting me around here and there I would end up in the hospital all the time but they couldn't keep me in there. Its just funny they didn't have services to help people and there is so little housing and thousands of people want housing (Kathy)

Kathy has dedicated much of her life to social justice goals, as a mental health consumer survivor, Kathy has done a great deal of work supporting folks with mental health by caring for folks' pets and her community, sometimes taking pets into her home and visiting/caring for people and pets through a community support service that she started. Kathy reflects on the ways she has supported her community: 
I had one woman who wasn't feeling well she had something going on and wanted to go to the hospital. So, I'd go over there everyday and feed her cat and brush her hair, I used to brush her hair for her; she was in bed and wouldn't get up (...) I told her about (a community organization) now she's a member and has been for years (...) see I help people by telling 'em where to go 'this is where you go you'll love it you can get some food it's cheap" (Kathy)

Kathy is a person who laughs often and easily, and loves to make others smile, she clearly brings joy to the people in her life. In addition to her social justice work and peer work Kathy is also a performer. Kathy often pauses at points in her story and says "I just love people" a sentiment that is clear in the ways that she works to build support communities. I compliment Kathy on her bright cat-themed wear. She tells me that she is definitely a cat person and must have been a cat in a past life, she describes her home as a cat paradise; with five cat poles and lots of space for cats to roam and play.

Kathy reflects on how her cat came into her life and her relationship with him during the time that she was homeless. During our interview Kathy often says that she is "lucky" to be in housing and talks about what being housed has meant for her and her cat who has since passed away:

I got my cat half way through my homelessness so I could go to those places and I could get my hair done and go to the hospital it was just near the end I got my cat. This woman at the hospital she didn't want the cat she wasn't well and I took him and I fell so in love with him. He was so cute he used to lick my tears away; he licked my tears. He'd go on one side of my face and lick my tears and then he would go on the other side of my face and lick my 
tears. He was too much, he was too much....he was so cute! I'm so glad I finally got him into a place and housing that he had a good life he had all those cat poles to climb (Kathy)

The participants I met with spoke to several themes that contribute to, and uphold issues around poverty and caring for an animal companion. As will be discussed at a later point in this chapter, the issues and themes that participants raised sometimes do not directly relate to their animal companions, but participants' relationships with their animal companions are a starting point to speak to broader more systemic inequities and marginalization. In this sense it seems that although pets were a central concern for all participants, the lack of choice around care for a pet, lack of choice in escaping violence, in housing security and other basic human rights, as well as ideological and systemic barriers appeared (unsurprisingly so) to be upholding this issue.

Participants highlighted many themes that contributed to their experiences, which will be discussed here. The three themes that I will be focusing on are; dominant gendered expectations and women as carers; the dismantling of the welfare state, neoliberal individualization/the neoliberal subject and women living in poverty; and violence: dual violence and gender-based violence.

\section{Dominant Gendered Expectations and Women as Carers}

A theme that was consistent among all three participants both explicitly and implicitly, through discourses that participants used, was around dominant gendered expectations of women and women as carers. I arrived at this theme by combining multiple categories that seemed to be in relationship with one another in the context of what participants described over and over within their interviews.

I created a category called 'Interdependence'; the way I framed and conceptualized this category was in that actions and ideologies that participants described seemed to be almost the 
opposite of neoliberal individualization. Interdependence includes the ways that the participants took care of those around them; this included community members, peers, children, partners and of course, animal companions. Many of the participants described their animal companions as 'family' or as a 'best friend' and also described the ways that their animal companion took care of them. Participants described a responsibility they felt to protect and care for both their animal and others around them, and the ways that participants felt that others were deserving of support unconditionally, which I framed as quite the contrast to neoliberal ideologies of individualization, a concept that will described in the next section.

Another very significant category that contributed to this theme was around 'women's work and dominant expectations/narratives of women', a category that I believe is also connected to neoliberalism. This category of 'women's work and dominant expectations/narratives of women' in particular came up and weaved through many aspects of participants' stories as they spoke of social expectations or internalized expectations of them as women. This category included codes such as 'good mother/parent/partner/pet owner', 'expectations to put others first', 'expectations to be 'responsible' and to 'protect and take care', 'not to be selfish', 'guilt' and 'self-blame'.

The final category that contributed to this theme is 'social justice'. This category is interesting because as previously mentioned I do not believe that it is a coincidence that all participants participated in social justice work regardless of the precariousness that many of them experienced or are currently living in. I also do not believe that it is a coincidence that all participants' companion animals are/were rescues. This category included codes such as 'social activism/advocating', 'higher calling' and 'social responsibility'. And though this category could be separate from this theme, I feel that it is interrelated, as much of the social justice work that the participants spoke of was unpaid emotional and/or caring labour, sometimes putting it ahead 
of their own livelihood and thus also related to the category of 'interdependence' and ultimately the theme of women as carers.

Thinking of women as carers and dominant expectations of women, Noreen recounts the selfblame she felt when she could not protect her cat from violence and the dominant narratives women are often subject to and sometimes internalize:

So yeah I was glad that the cat learned that it disturbed me greatly that my being there led to that. Right now that sounds like a lot of self-blame to carry, it was. But umm the prevalence at the time right kind of I mean when you're in an abusive relationship so much is your fault it seemed easy enough to take on the responsibility of the cat getting abused is you know "well you should have done something” (Noreen)

As will be discussed at a later point in this chapter, this theme of 'women as carers and dominant genederd expectations' significantly bumps up against neoliberal narratives of 'deservingness' and individualized blame. As Natalie recounts below;

It was horrifying and I thought it just couldn't get worse, here we found ourselves at the shelter and then having this pastor of the church start telling me how selfish I was because I wasn't willing to give my dog up. “you're very selfish and I don't know how your husband lives with this" I was like I'm sorry I'm trying to take care of my family member my dog and he was like "no you have to give your dog to someone who has means, you don't, you have no business having a dog" (Natalie)

Kathy while reflecting on her housing and how this makes more space in her life to care for others and do social justice work says: 
having that place changed my life around to do the work I do advocating for homeless and people with pets. That's why I started that program and I did that for free that was a free service I gave because I knew what it was like to be homeless and have your cat (Kathy) Kathy goes on to tell me about the recognition she has received for her community and advocacy work. I said to her that it sounds like she is such an advocate in her community and she speaks about interdependence:

yeah and other people help me too other people do it too, because were all supposed to love each other and have a good life, because life is too hard (Kathy) What is also interesting about this theme is that the participants sometimes describe this expectation to care for others or a want to care for others, a gendered expectation that often falls dominantly on women. At the same time, some of the participants describe that this expectation becomes blurred when a pet is the family member being cared for; this is often where blame comes into the picture as described by Natalie above and here by Noreen reflecting on what she was hearing from those around her:

I mean the cat was my cat and you wouldn't want to leave your family member isolated and alone why would you want to leave your cat isolated and alone. I mean the cat, was you know my family so it was really hard to leave him alone (Noreen) But Noreen also experienced conflicting expectations, on one hand she wanted to care for her family and on the other she was sometimes blamed for not taking the right kind of care, for not caring for her abusive partner and for further possible violence:

so it was really hard to leave him alone and have other people say you know "why are you worried about this or why are you going back there to feed the cat or spend time with the cat if you know that that opens you up to further abuse or possible abuse" (Noreen) 
I had lots of friends but many of them were not aware of issues of violence against women, so although they were my friends they would you know think that I should be more hmmm be more compassionate to this person [the abuser], you know he was unemployed and you know things like that, there was friends in my life but not that they were what I needed (Noreen)

The dominant ideologies around care work in its many forms are often gendered. As discussed by participants, expectations to take the 'right kind' of care as well as other dominant discourses around what it means to be a "good" mother or parent, partner or pet carer impacted participants experiences. As discussed by Meyer (2000), unpaid and undervalued care work often disproportionately falls on the shoulders of poor women and racialized women. And this is not to essentialize women's experiences, or women more broadly, but rather what I would like to speak to here are the dominant expectations, ideologies and stereotypes impacting women's experiences and potentially participants' experiences, as this is a notion that participants speak to whether explicitly or implicitly. As discussed by Eisenchlas (2013), in relation to dominant gendered roles "women are generally thought to be communal—-that is, friendly, warm, unselfish, sociable, interdependent, emotionally expressive and relationship oriented" (p. 2); these gender roles are both descriptive and prescriptive, are often naturalized.

It is no surprise based on these stereotypes and dominant ideologies around gendered expectations that women are often doing the caring work, especially within a neoliberal climate where there are greater reductions to the welfare state and therefore fewer social supports and a greater need for care. As discussed by Nadasen (2013), Neoliberalism, which will be discussed in more depth in the next chapter, has worked to 
[dismantle] the economic safety net, trend toward privatization, and the rise of the security state have increased the burden on women. The reduction or elimination of welfare benefits for the poor, cutback of social services, and reliance on market strategies, [...]have led to a crisis of social reproduction and a corresponding increase in women's workloads. With a decline in social rights and publicly-funded support services, women have access to fewer economic resources and must either turn to the private sector or increase their own unpaid labor. In this way, neoliberalism has intensified women's oppression and exploitation. (para.2)

Further to this, the costs of care work as discussed by Meyer (2000), which often go unacknowledged and unpaid are significant, particularly for racialized women and women living in poverty; if these costs were acknowledged and these gaps filled, there may be greater space for equity:

The costs of unacknowledged and uncompensated care work are enormous, particularly for women, the poor, and persons of color. Socializing the costs of dependency through welfare state programs represents a great opportunity to ameliorate inequalities. (p.3)

However, this is not to imply that care work is unnecessary; quite the contrary, interdependence and mutual care are actually highly necessary particularly within neoliberal conditions of hyper-individualism. However, the ethic and value of care and care work, also within these capitalist, neoliberal, colonial and patriarchal conditions also contribute to genderbased marginalization. As discussed by Williams (2018), when looking to care ethics; migrant, poor, and racialized women are often in low paid and undervalued care labour positions and because this type of work is undervalued, along with racism, colonialism and neoliberalism, it contributes greatly to marginalizaion and inequity. Further, within a neoliberal, colonial society 
that values hyper-individualism and autonomy while devaluing 'dependency', interdependence, and vulnerability, it is no wonder that care work, both of the carer and the cared for is undervalued and relegated to the work of marginalized folks. As discussed by Williams (2018):

The economic value of supporting care needs is that it is cumulative: the more people are supported the better they are enabled to provide care for others, and this promotes solidarity. (...) This economic argument is based upon the ethics of interdependence, mutuality and universal human vulnerability rather than on individualism and self-sufficiency. (p. 557-558) Simply put, we need one another. Contrary to what neoliberal ideology would imply, the crux of it is that we need one another more then ever, especially within the current political capitalist and neoliberal climate, a concept that some participants spoke to so eloquently when reflecting on the ways that they care for their animal companions, family, and community.

This brings me to the concept of what Nakita Valerio calls Community Care. Valerio wrote recently about the need to scrap self care, a concept that is often dominantly touted as important to our health and well being, but is actually latent with neoliberal ideologies of individualism, and instead focus on community care (Dockray, 2019). As discussed, all participants were involved in social justice work or had a deep commitment to social change work in some way, in addition to the care that they provided to pets, family and community. This concept relates to the category of social justice work and interdependence in many ways (Dockray, 2019). As discussed by Valerio in an interview "community care [is] "People committed to leveraging their privilege to be there for one another in various ways". Yet this form of care isn't entirely selfless, at least not in the long run. "They (the care providers) know that when they will also need care in the future, others will be there for them" (Dockray, 2019, para.5). And though this type of support and care is greatly needed, especially within the current social and political climate, I 
wonder how it would impact participants' lives if this care was given greater value, was paid or was less urgent because of the lack of alternative social supports for participants and their communities.

\section{Dismantling of the Welfare State, Neoliberal Individualization/the Neoliberal Subject and Women Living in Poverty}

The next theme that was the most prevalent among all research participants' stories was around neoliberalism broadly and all the impacts of neoliberal ideology. As discussed by Baines (2011), Neoliberalism is "an approach to social, political and economic life that discourages collective or government services, instead encouraging reliance on the private market and individual skill to meet social needs" (p.30). This includes a shrinking and dismantling of the welfare state, which means a reduction in social supports and policies aimed at reducing inequity; instead, with further reliance on the private market, privatization and hyperindividualism of citizens (Nadasen, 2013). With this comes an 'every person for themselves' dominant ideology, where citizens are expected/ deemed to be rational actors using their individual choice (and buying power) to support themselves with little support from government. "However, as many authors have argued, because neoliberalism promotes the idea of a rational individual exercising free will while eroding social democracy, it has made life harder for most women and has widened the race/class divide among women [leading to greater inequities, poverty, precariousness and marginalization ]" (Nadasen, 2013, para.1).

Additionally, neoliberalism goes beyond market or government-imposed policies and reductions in the welfare state, but also impacts dominant ideologies around citizenship, constructing who is considered the 'ideal neoliberal citizen' and dehumanizing, marginalizing and punishing those who are not considered the 'norm' (Boyd et. al., 2016). With neoliberal 
individualization also comes an individualization of social issues; an ideology and rhetoric that places blame on individuals for social problems as a self-deficit, for 'not working hard enough', 'being/not being a productive member of society' and then constructing folks as either deserving or undeserving of support.

Many of these themes were reflected upon by participants, and in multiple instances these themes around neoliberalism, I felt were also connected to some of the dominant gendered expectations that participants expressed such as those around women as carers and other dominant expectations of women. This theme came up both explicitly and implicitly within participants' stories of their experience and was probably the most salient of the themes here. Many of the categories I created in my analysis related back to this theme in some way.

To arrive at this theme, I combined multiple categories: 'individualization of social issues', 'deserving/undeserving', 'surveillance', 'rights vs. charity', bounded choice' and 'precariousness'. It is important to highlight the ways that some codes crossed over between categories and/or themes, indicating that perhaps there is a relationship between the themes impacting participants' experiences. For Example, the code 'good mother/partner/pet owner' fit within this theme around neoliberalism as well as the theme of gendered expectations, indicating the messiness of experience around where neoliberal expectations about the 'ideal subject/citizen' differs based on subject position and other interrelated systems of marginalization such as patriarchy. Other codes that I feel are important to highlight which contributed to the categories and theme are 'luck', 'deservingness' and 'blame'; these codes came up within multiple contexts within all the participants' stories. 
I was lucky enough my husband was able to borrow a little bit like $\$ 100$ from a friend who said “don't worry about it I don’t actually expect it back I know how hard it is or you right now" and it's humiliating for my husband (Natalie)

And I struggle with my emotional health because of this and I'm told "well suck it up there is nothing I can do. In this day and age you're lucky that you just have a job" (Natalie)

and it was awful because it just felt like we were spinning our wheels and we couldn't get any supports from any agencies because we had jobs. So you have a job you should be able to provide this that and everything else for yourself and it just doesn't work that way. And when you have this crappy minimum wage job and you're banging your head against the wall trying to survive no one will help (Natalie)

I thank the, I thank, I thank my lucky stars that I have a safe place to live, I'm so happy, I'm so lucky (Kathy)

Thinking about luck in relation to this theme and the category of rights vs. charity for example, talk of luck (luck in this context was related to luck in finding safe/affordable housing, or lucky to have friends or acquaintances that can lend money or offer temporary housing), what participants describe as 'luck' are often human rights and entitlements that due to neoliberal individualization, the dismantling of the welfare state, and discourses of who is dominantly constructed as deserving/undeserving, puts responsibility back onto individuals to care for themselves. People living in poverty may have limited choice but to hope for 'charity' in place of entitlements through the welfare state (such as safe affordable housing, adequate employment, 
adequate social supports), placing folks in precarious situations and with a need to prove their deservingness for such 'charity'. For example, as discussed by Bullen (2015), neoliberalism and advanced liberal rationalities have affectively replaced the welfare state, a state that is meant to offer rights and entitlements to citizens, with a state that instead promotes surveillance and monitoring of conduct (hence the need to prove deservingness):

Under these advanced liberal rationalities, problems such as poverty and homelessness are conceptualized in terms such as "dependency", "exclusion" and "risk" rather than in terms of changes in the labour and housing markets, or by social issues such as domestic violence [or within broader systemic issues]. (para. 16)

As mentioned, along with 'luck' and 'charity vs. rights' is 'deservingness', a code that greatly contributed to this theme around neoliberalism and neoliberal ideology. Deservingness came up many times among all participants within various contexts. Here Natalie reflects on being constructed as undeserving of support:

I understand for people who are on OW and here on in its going to be so much worse for them and here I am with a minimum wage job being told I “don't deserve help you've got a job". That's like the magic poof "you've got a minimum wage job you should be fine now". But I have nothing, I'm in an apartment with nothing, sleeping on a hard floor with nothing, using my winter coat as a bed (Natalie)

this particular [Ontario Works] worker, some of them are ok, some of them can be very unkind, this is when they were pushing this work fair back in the Harris days, It was really disheartening to hear "what makes you think you deserve to go to school you're on welfare" that's exactly what she said [to me] (Natalie) 
Kathy reflects on her first one-bedroom apartment after experiencing decades of homelessness, she recalls how she didn't unpack for a year because she felt she didn't deserve it and thought she would be evicted. Kathy also highlights the way she was constructed by social service workers, speaking to a need to prove herself deserving of support and of housing:

And then I finally got my first one bedroom apartment and I cant tell you, I had windows I could see out, I had my own bedroom, I had a little pillow; can you imagine my own pillow, its unbelievable, and a fridge and stove it was just amazing but I didn't think I deserved it; I kept thinking I was going to get an eviction notice (Kathy)

Now I never drank when I was on the street because it was too scary but I became an alcoholic and I drank for years but then I just stopped cold turkey because its just not healthy for you because you drink to ease the pain and so but it's sad because they didn't treat me too good at first “oh just another homeless person we'll just give her a sandwich and goodbye" but after they got to know me that's when they helped me get into housing they helped me and sent me places, watched my cat and cage, I went for interviews and its pretty funny I got my own apartment, I couldn’t believe it, oh my goodness (smiles). I couldn't believe it (Kathy)

Here Noreen reflects on being constructed by others as undeserving of her companion animals: Oh my god! like as if you're not allowed that you know, everything else is taken from you, your dignity and so much more, and then on top of that you're not allowed the companion animal because you can't afford it. Like the doctor actually told me well you might wanna consider putting her down it's a challenge to do it on disability (Noreen) 
As previously discussed, in addition to folks living in poverty being constructed as 'undeserving', participants also highlighted dominant discourses of blame. Within neoliberalism social issues, such as poverty are often framed as individual 'failings' or 'inadequacies' and folks are often blamed for these so-called 'failings' (Bonnycastle, 2006). Blame came up on multiple occasions within participant interviews, and was also sometimes related to 'self-blame' (internalization of dominant ideologies, stigma) and 'judgment'. Below, Natalie speaks to blame and the individualization of social issues;

if you're homeless you must be on something it's never considered that maybe there is a life situation that brought this on, tragedies happen everyday but stigma still exists .... and it's very much, your bad choices (Natalie)

The next category that contributed to the theme of 'dismantling of the welfare state, neoliberal individualization/the neoliberal subject' was surveillance and criminalization. Surveillance is an intentional and ideological tool of control and discipline that further marginalizes low income people and people living in poverty. As Moffatt (1999) describes, surveillance can happen in social assistance offices for example where folks living in poverty are watched, scrutinized and disciplined, constantly needing to prove need and deservingness.

The concept of surveillance is furthered by Foucault's concept of governmentality. Governmentality refers to the way government can 'govern at a distance' this is done not always through force (but definitely can be especially in the case of criminalization and over-policing of poor and racialized communities) but often through discourse and ideology and includes the ways that we govern one another's conduct and the ways we may self-govern (Bullen, 2015). For example, through dominant discourses that say the 'ideal' neoliberal subject must be a particular way to be considered valuable or even human (i.e.; white, cis-gendered, male, not disabled, sane, 
have class privilege, etc.), folks who do not fit this dominant norm are surveilled, blamed or disciplined. Because nobody is an island unto themselves, it is easy to internalize these expectations and self-govern or self-surveille to live up to these norms. This is where the code 'normal' came into this category around surveillance and neoliberalism. Participants sometimes expressed their desire to be 'normal', a discourse we are all subject to and often unconsciously internalize, self-governing to fit the constructed norm, and often knowing that being constructed as the 'other' means experiencing dehumanization, stigma and marginalization. Here, Natalie reflects on being surveilled, constructed as an 'other', criminalized, dehumanized and disciplined by staff at the hotel she was staying at with her husband and dog:

and they were like "no, they can't stay here they are vagrants" and it was so humiliating and the police came in and they were like "they don't want you back here" and there were people looking at us(...) and I remember the hotel manager saying "I don't like that you're giving those vagrants that food, but if you must give it to them they must go outside" (long pause)... I mean we didn't look different than anyone else; I was wearing a black collared shirt and black pants; but they didn't want the hotel guests seeing 'the vagrants'. And it was so humiliating for me I took my dog outside and gave her the food and sat there in disbelief and I felt like I wasn't a human being, I thought I don't, I felt like I didn't matter, I felt like is this what we are? I guess this is what we are (Natalie)

Here Kathy reflects on her experiences around the intersections of sanism and poverty and reflects on the surveillance and criminalization of folks living in poverty:

listen here because I had schizophrenia and was an exotic dancer they charged me with this person's death and you know how I got off? Cause they couldn't find a psychiatrist to say a person who is schizophrenic grows three inches taller, that's the height I had to be to do the 
crime and I wasn't even there; see the stigma what they do, its terrible you know, how many people that are homeless are in jail for something they didn't even do? (...) the system is terrible they just want to go out and do it, like I had a colorful life you know (laughs) it's terrible and then they put me in (hospital) that's a psychiatric place to go to court, but I got off because I wasn't three inches taller, but could you imagine if I was the same height as that guy I would have been in jail for something I didn't even do (Kathy)

Finally, I would also like to highlight the category I called 'bounded choice' which contributed greatly to this theme as well. By bounded choice I am referring to the ways that participants described precariousness and poverty in their lives impacting decisions. 'Bounded choice' indicates times when participants had very limited options in caring for themselves, their family or their pet forcing a choice that is painful or difficult either way. In the next section I will discuss 'dual violence' a category that is related to 'bounded choice' however differs slightly where the choice on either side results in or threatens to result in violence.

Bounded choice however relates back to the theme of neoliberalism in multiple ways. Neoliberal ideology often highlights the virtues of 'rational' choice/actors exercising free choice in a market driven society where the welfare state and social supports are greatly reduced (Nadasen, 2013). This restructuring and dismantling of the welfare state aim to create 'responsiblized citizens', which essentially means we are expected to take care of ourselves without entitlements, and if we cannot, we are then blamed for our own 'bad decisions' 'laziness' and so on, as described by participants above (Bonnycastle, 2006). This ideology of 'responsiblized' citizenship and individualized responsibility is a trap, because as described by participants, the old adage of 'pulling oneself up by the bootstraps' within a climate of precarious employment, housing, a lack of social support and globalized hyper-capitalism means that 
marginalized folks living in poverty are left with a complete lack of choice and support as highlighted by Natalie and Noreen below.

there is no choice.. and like I said to be employed and to be so close to that everyday being on that verge where you don't know sitting having those difficult discussions every night "do you think we can stay here next week" and then counting out if something were to happen is there somewhere we could stay, we might have to sleep outside, is there a safe place? And that never should be a reality for anyone. I know that sounds unrealistic for me to say that but that shouldn't have to be a choice (Natalie)

I wanna be vicious and say it would mean I wouldn't cringe when I go buy cat food, but that's really where I'm at you know, like I pass over the money and I'm thinking ok what can I cut from my food bill to make this happen or what do I have to cut from my food bill to make this happen, and that's a horrible feeling when you're talking about one of your best friends, you know that's not cool (laughs) there is something really wrong about that because you feel really bad and really torn and really guilty, for no reason like (Noreen)

you know it's just really hard and I wish I didn't feel guilty about them [the vet clinic] going "you haven't brought her in yet" and having to stand there and explain to them "yes I haven't: I'm unemployed, I don't have a job, I don't have an income, and I really am trying" (Noreen)

\section{Violence: Dual Violence and Gender-Based Violence}

The final theme that weaved through all participants' stories was about violence, both genderbased violence and a category I named dual violence. And, though it was not a qualifying 
criterion for participants in this research, all participants were survivors of gender-based violence.

I arrived at this theme by combining categories I named 'violence/gender-based violence', 'dual violence' and 'disenfranchised grief'. Dual violence is in some ways similar to bounded choice, and in some parts of participants' stories there is overlap of these themes; however, it seemed to me that that participants were sometimes describing something that was far more painful for them than some of the parts of interviews I would have coded as 'bounded choice'. Dual violence is about harm participants experienced, sometimes because of a bounded choice, and sometimes in relation to aspects of identity such as gender, which is why I grouped both gender-based violence and dual violence in the same theme.

Further, 'dual violence' also refers to multiple types of violence such as experiencing poverty, homelessness, physical or emotional violence while also experiencing the violence in the loss of or threat of loss of something that is loved or important, in this case a beloved animal companion. The category of disenfranchised grief contributed to this theme because it seemed that the dual violence participants experienced, especially where a beloved animal companion was concerned, meant that there was little space for their grief and pain. For example, Noreen recounts her experience of escaping a violent relationship and what she calls a 'damned decision' in being forced to leave her cat behind:

Certainly, I had people coming to look after the cat, change the litter, put food down once a day or once every couple days um it was a neighbor of mine, but ultimately the cat was on its own and that was really a damned decision for me there isn't a moment that went by that I wasn't upset and second-guessing my decision (...) feeling bad for the cat, and feeling sorry for the cat, and not knowing whether I should go back. But going back would have meant 
outing myself so to speak because clearly, he knew where I lived, so yeah it was a really difficult time with really difficult decisions and the cat was certainly a major part of that decision making that I had to do, it was horrible leaving the cat there (Noreen)

Here Kathy recounts her experience of homelessness and the threat of violence to herself and her cat, she begins to cry as she thinks about what it would have been like to lose him:

yeah it was so hard cause I had to take the cage, I had a collar he would play out in the grass for a while, and he would go to the bathroom once in the morning and he'd go a couple times and I had to be very quiet there was nothing worse in living in the park on the grass with a blanket under the bushes so no one can see you and you hear little bugs and things crawling, and you don't know what they are, and its just devastating. I used to cry every night. Well you're scared to fall asleep cause you hear these noises and people are walking through the park and it was a parkette and I'd stay away from the homeless people because they'll beat you up and take your stuff and I couldn't I could not lose my cat, that would be the end of me... and I'm getting emotional .... and I loved him (Kathy)

All of the participants speak in some way, in relation to keeping their pets, to 'loosing everything else' or about 'everything else being taken from you' a sentiment that I felt spoke to the violence of dehumanization, a lack of care or regard for the participants' relationship with their animal companions, disenfranchised grief and ultimately dual violence. Here Natalie recounts her experience of accessing a shelter and the threat of her dog being taken away:

how people could be that way. It was horrible and then having the director of the shelter laugh while I'm crying telling me I'm going to have your dog taken away from you (...) I have fought for years to be able to keep my dog up to the point where things when we lost everything the way I looked at it I would say to my husband "but we didn't lose her" and at 
the time that was the biggest thing for me. OK You're going to take everything away please don't take my dog. I can deal...Like if I have to lose material things, I like my things, but they don't define me. I'm not attached to them in a way where I die, but you can't take my dog that's totally a different thing (Natalie)

Finally, all three participants discussed surviving gender-based violence at various points in their stories. Here Natalie recalls surviving a violent relationship where a beloved pet was killed and talks about her time healing with her children:

Yeah so, so almost 7 years ago (husband) and I got married and for a very long time I had not because I had lost a cat in a phase of addiction I did not know that my partner, he, it was a very co-dependent relationship and he was very abusive and he had thrown my cat outside and basically, she had got hit by a car (...) and he didn't tell me and I recall walking the streets calling everywhere looking for her so that was a really hard thing for me to heal from but I had to get better, heal with my children and then heal from that (Natalie) Kathy talks about surviving rape, substance use and resiliency in dedicating her life to community work:

I cut my drinking cause I have liver damage, so I cut cold turkey and I used to drink to um, cause I remember all the stuff I went through being raped and all those kinds of things, so I drink to ease the pain even though I had a nice place I still drink because I was used to drinking and it was when I got liver damage I was like "no I need to stop I'm getting older now and I wanna live". I got more work to do I gotta help more people so that's why I'm gonna be around awhile (Kathy)

Gender-based violence, both intimate partner violence and other forms of state and systemic violence were aspects of all participants' stories. As discussed by Gill (2018), Gender-based 
violence, both interpersonal and state violence is heightened for women, LGBTQ people of colour, racialized and Indigenous women. As Gill (2018), writes

Those of us working to reduce communities' experiences of intimate partner violence, and to support survivors of violence, understand that there are systems of power and inequity within personal relationships that cause and exacerbate violence, and make help-seeking difficult. In addition, there are systems of power and inequity outside of the relationship that scaffold intimate manifestations of violence. (para. 2).

Any exploration of gender-based violence must be intersectional and consider historical context, intersecting and interlocking systems of oppression such as racism, colonialism and transphobia among other systems of marginalization that have historically and currently worked to marginalize and impact experiences and prevalence of gender-based violence, where women living in poverty, racialized trans folks, and particularly Black trans and cis women experience increased violence. As discussed by Gill (2018), "intersectionality (Crenshaw, 1991) allows us to examine the unique ways gender overlaps and connects to survivors' experiences of race, health and ability, immigration status, sexual orientation, housing status and other marginalized identities" (para. 2).

Further, poverty, unemployment and housing status have been shown to exacerbate violence and intimate partner violence, a theme that was discussed by all participants to some extent. Though participants indicated gender, sexism, class, sanism and disability as impacting their experiences of violence, poverty and marginalization, it is also important to highlight that in Toronto and elsewhere, race, and racism greatly impact women's experience of violence, access to housing, employment and income levels (Khosla, 2008).

Further as discussed by Khosla (2008), homelessness among women is rarely captured in 
shelter statistics or street images because of the constant threat of violence for women experiencing homelessness, living outside is often not an option (especially for women with children, where living outside would likely mean losing their children). However, as discussed by participants, accessing a shelter for every one of them was a non-option due to pets not being allowed in most shelters. As participants described, this bounded choice often contributed to dual violence in being exposed to or experiencing violence either from having no choice but to stay outside, as Kathy and Natalie describe, or delaying leaving a violent living situation due to concern for a beloved pet, as Noreen recounts.

\section{Conclusion and Relationship Between Themes}

Finally, in terms of the ways the themes relate to one another, I noted that there seems to be a relationship between sexism and gendered expectations of the neoliberal subject (such as women as caregivers) and neoliberal individualization. Though participants never explicitly say this; they describe these expectations that they 'take care' (in a very particular way, which includes pets); this narrative seems to bump up against neoliberal, colonialist ideologies of individualism, along with surveillance of women living in poverty to conform as the ideal neoliberal subject otherwise be, blamed, shamed and constructed as undeserving.

In some instances, it seems that participants were caught in a dual violence/double bind between these conflicting dominant narratives/expectations that on one side say 'do the gendered caring work', 'keep family together' 'be a good parent/partner/pet carer' and on the other side say 'you are not doing it right and do not deserve support'. These narratives and ideologies seemed to contribute to participants' experiences and were also combined with patriarchal violence/ gender-based violence, a form of oppression that is not dissimilar to/also upholds neoliberal colonial discourses and structures of marginalization and violence. 


\section{CHAPTER 5. IMPLICATIONS AND CONCLUSIONS}

As has been explored here, the research questions that I used to guide this research project, were from my own subject position. As a person who is housed, and in a position of significant privilege, it is important to acknowledge the ways that this research was a co-construction between myself and participants and also the many ways that I held/hold power in this research process. In the short time available to complete this major research project there were aspects that I feel would have been better decided by community; the research question being one of them. Though participants identified that the guiding research question resonated with them, these questions were created based on my own experience and subjectivity. Revisiting this, my research question was: 'what barriers exist for people living in poverty with pets in accessing support or services? How is the 'validity' of pets as a source of support for communities living in poverty discursively created/constructed?'

It seems that the barriers that participants experienced manifested in multiple and unique ways based on subject position, and intersecting identities. However, one thing that seemed clear from participants is that though barriers often manifested in very concrete ways, such as through bounded choice, lack of access to shelters, a reduction in social supports, precarious housing and employment among others, many of the barriers were also ideological in nature having to do with the ways women living in poverty are constructed and valued, along with other sites of oppression that participants described such as ableism and sanism. All of the participants I spoke with described the multiple systems of marginalization impacting their experiences, and thus impacting their relationship with their animal companions. In this sense the value of a pet as a source of support, as my research question asks, seems to be connected to the value that is given to marginalized folks who care for pets. Though participants reflected on what their pets 
mean/meant to them and how that relationship constrained decisions, much of participants' stories also focused on the systems and structures of oppression in their lives that deeply constrained their options and access to, or availability of supports.

So simply, my interpretation through data analysis is that barriers are often ideological first, constructing folks living in poverty in particular ways, these dominant ideological value positions contribute greatly to the types of supports that are available and also to further marginalization of people living in poverty with pets. For example, Natalie reflects on how alone she has felt trying to support her family through precariousness, and homelessness saying that it seemed nobody cared about her relationship with her beloved dog, whom she was desperately trying to keep in her life. Here, Natalie talks about what changes need to happen:

So you've got these shelters which are non helpful you cant have your dog with you, even if the dog is registered there is not a lot of hope that will work out, there needs to be more facilities there needs to be more conversations about this (...) and right now the ground is so shaky and I really do hope that something happens where maybe this becomes important; and I know that for government it will never be. But there needs to be more support, and I don't know what that would look like (...) there needs to be more housing, shelter not like the ones we have now, there needs to be places where there is a little more dignity, and I did as an addict getting my life together, I stayed at a shelter for months. I was there for a very long time and I've seen everything and if you look at not far from there you look at (another shelter) that is a horrible place is and absolute nightmare, there is no dignity (Natalie) As Natalie describes, people living in poverty in Toronto have few if any options. Folks are often dehumanized, and with a lack of government priorities, and a shrinking of the welfare state; social supports, let alone dignified social supports, are few. As Kathy describes below folks 
accessing social support programs such as ODSP also have few options, as she recounts having to leave a job she loved because of fear of her ODSP being cut and becoming homeless again. Kathy calls for changes to social assistance programs that support poverty reduction:

I started ODSP and I was working so I had to pay my housing so much money, and I had to pay ODSP so much money, I was working for nothing I had to quit. Well they'll take half and the other half so I have nothing to live on, so I had to quit the job cause I had couldn't pay my rent.. isn't that awful (...) I don't know how people get ahead if they would have let me work a year without taking it off I could have saved some money then I could have maybe made it and kept my job. But I left (...) it's terrible if they give people a chance they say they want people off ODSP but give them a chance if they get a full time job don't take their money, give them a year to get on their feet cause they don't have nothing, cause they could save some money well then they'd be cut off ODSP (...) you wont get back on it you'll be suspended and you'll have to go on welfare and that's so that's why. And that's another thing that scares people from getting a job "why would I get a job, if I lose it I'll be back on the street" so there's so many obstacles in the way of people I mean like I loved that job but I had to quit (Kathy)

Noreen speaks to a similar sentiment. In addition to community programs that recognize pets, Noreen says that there needs to be better community funding as well as social supports for individuals to alleviate poverty:

Yeah let's see, ummm resources like (...) these rescue organizations I wish there was better funding for them, umm because they can do what they can do but they cant do everything um and now that I know they exist, I definitely would have looked into it closer had I have known at the time so yes some better funding both for myself personally but for community 
organizations right (...) and I mean shelters it would be a challenge I think to have shelters that allow women to bring in their animals; however, I don't know if you're aware but Fred Victor has a shelter for homeless people right that allows them to bring in their animals I don't know much about that but I think it's a fabulous idea (...) so that would have been helpful.. supporting more ideas like that in community would be helpful, so yeah funding shelters, supporting shelters (...) It would be nice if there was something like that but with ongoing support for chronic issues, now it would be nice if the humane society opened up its doors and said we have a vet available, that would be nice for low income folk (Noreen) In short, the implications for social work in regards to people living in poverty and their companion animals are many. As was described at the beginning of this paper, my motivations to explore this area came directly from my experience in the field working to support folks living in poverty accessing, or wanting to access supports with a companion animal, while experiencing significant barriers, and often a complete lack of care or options. Further, reflecting back on the grassroots initiative I described at the beginning of this paper, I am again reminded of the many ways that this initiative is a response to larger systemic oppressions and marginalization, and the ways we must remain committed to systemic change so that a support like this may, one day, no longer be needed. Because issues around poverty, and more specifically here, women living in poverty are multidimensional, interconnected with broader systems of oppression and interlocking systems of marginalization, the answers as well are not simple or prescriptive- I can only query what social change might look like and commit to working toward that change.

From a social change perspective working from a place of anti-racism, anti-colonialism, and challenging neoliberal ideologies that uphold systems of marginalization must be a lifelong commitment both for social work and for myself. Social work within neoliberalism for example 
is not innocent in this, nor am I, with significant reductions to the welfare state social work is at risk of becoming further depoliticized. Instead of focusing on challenging social inequity for example, within neoliberalism, social work becomes a site of further surveillance of marginalized folks. Social workers are expected to do more with less funding; and social supports take on market driven goals that individualize social issues, remove entitlements and rights, and force service users to prove a need for support (Baines, 2011). As participants of this research study so eloquently said over and over; both ideological and material shifts must take place in order to build a more equitable world. 


\section{APPENDICES}

\section{Appendix A-Consent Form}

Ryerson

University

SCHOOL OF SOCIAL WORK

FACULTY OF COMMUNITY SERVICES

Ryerson REB Protocol Number 2019-009

\section{Ryerson University Consent Agreement}

You are being invited to participate in a research study. Please read this consent form so that you understand what your participation will involve. Before you consent to participate, please ask any questions to be sure you understand what your participation will involve.

\section{TITLE OF THE STUDY}

People living in poverty with companion pets: Barriers to access and support

\section{INVESTIGATOR}

This research study is being conducted by Joanna (Joey) Violante, I am a Master of Social Work student and am conducting this research in partial completion of my graduate degree. This research study is supervised by Dr. Samantha Wehbi from the School of Social Work at Ryerson University.

If you have any questions or concerns about the research, please feel free to contact Joey Violante at jviolant@,ryerson.ca or Dr. Samantha Wehbi at swehbi@ryerson.ca.

\section{PURPOSE OF THE STUDY}

The purpose of the study is to explore the barriers that people living poverty with companion pets (specifically dogs and cats) experience in accessing social support services as well as the choices that individuals with pets must make in accessing services while caring for a pet.

4 participants 18 years of age and above are being recruited for this study. Eligibility criteria for participation will include self-identification of either living in poverty, experiencing housing insecurity, living in or exiting/has exited a violent living situation (in whatever way that is defined by participant). Participants will also currently be in care of or have recently been in care of a pet (cat or dog) and accessed or wished to access social service supports such as housing support, shelters, mental health supports or be contact with systems involuntarily such as mental 
health systems and the criminal justice system. Participants will self-identify as having experienced barriers to access due to a pet or loss of a pet due to these barriers. Participants will be living in the Greater Toronto Area

This research is being conducted by a graduate student in partial completion of a degree requirement and the results will contribute to a major research paper as well as future presentations or publications.

\section{WHAT PARTICIPATION MEANS:}

If you volunteer to participate in this study, you will be asked to do the following things:

- Attend a one-on-one interview session, you will be asked to share your experiences of living in poverty with a pet in whatever way you feel comfortable sharing

- Our interview will be audio recorded for reference and you can ask for the recording to be paused at any time. The recording will not contain your name, but could contain identifying information/ stories. This recording will be kept in strict confidence and will be erased after the interview has been transcribed; transcription will omit any identifying information. You may also review the transcripts of our interview for accuracy.

- You will also be asked to share your experiences of barriers in accessing social supports and the choices you need to make to care for yourself and an animal companion

- You will be asked questions about grief or loss of a pet

- Our interview will take a maximum of 2 hours to complete and you are free to pause or end our meeting at any time

- The expected location of the interview is Ryerson University library building at 350 Victoria St. Toronto, but another mutually agreed upon location is also possible if more convenient for participant; as long as the location ensures privacy

- Research findings will be available to participants and can be sent via email, mail or picked up

\section{POTENTIAL BENEFITS}

My hope is that participation in this study will make critical the issues of people living in poverty and/or violent living situations with pets and the difficult choices individuals must make between a bond with a beloved pet or accessing services. My hope is that through engaging in these conversations participants will have a space to tell their story as they see it, and create further understanding of this issue. As a member of the board of directors for an organization with a mandate of serving people living in poverty and/or violent living situations with animal companions in providing alternatives to the loss of a companion animal, I am also hoping that the findings of the study will contribute to better services.

Though I cannot guarantee, however, that you will receive any personal benefits from participating in this study, my hope is that we can bring further attention to the experiences of individuals who need to make a choice about the care of a companion animal in times of crisis and create a space to talk about loss and support in its many forms.

\section{WHAT ARE THE POTENTIAL RISKS TO YOU AS A PARTICIPANT}


Because of the personal nature of the questions asked, a participant may reflect on unpleasant memories while responding to questions. These memories and stories may be uncomfortable or difficult to talk about. If you begin to feel uncomfortable, you may skip answering a question or stop participation, either temporarily or permanently. In addition, a list of community resources will be provided to you at the beginning of the interview. The interview will be audio recorded for transcription purposes and some participants may find this experience uncomfortable. Participants can ask for the recording to be paused or stopped at anytime, can take as many breaks as needed and can ask to end the interview at any time.

\section{CONFIDENTIALITY}

Your confidentiality is the highest priority in this study. A pseudonym will be given when referencing your story in the final research. Other identifying information such as names of agencies, other individuals, pet names will be anonymized or removed.

Your information will only be accessed by the primary researcher and if needed transcripts of our conversation with identifying information removed, may be shared with research supervisor. Your identifying information will not be shared, however, the findings of this research will be shared, with all identifying information removed.

The interview will be audio recorded. Interview recordings will be kept on a password protected cell phone and will be deleted immediately after being uploaded to a password protected Ryerson Google drive and the electronic recorded interview file will be deleted once research is completed in August 2019.

Transcripts of the recording will be stored on a password protected Ryerson Google drive and destroyed once research is completed in August 2019. Consent forms will be scanned and stored on a password protected Ryerson Google drive and deleted one year after research is completed. A limit to confidentiality would include disclosure of child abuse, or animal cruelty as the researcher has a legal duty to report.

\section{INCENTIVES FOR PARTICIPATION}

Incentive will be offered as a \$15 Tim Hortons gift card to participants.

\section{COSTS OF PARTICIPATION}

Cost of participation could include transportation to the interview location, TTC fare/tokens will be provided to participants as needed. Cost of participation including parking, gas or other costs will not be reimbursed.

\section{VOLUNTARY PARTICIPATION AND WITHDRAWAL}

Participation in this study is completely voluntary. You can choose whether to be in this study or not. If any question makes you uncomfortable, you can skip that question. Consent in this study is ongoing, you may stop participating at any time and you will still be given the incentives and reimbursements described above. If you choose to stop participating, you may also choose to not have your data included in the study; please indicate this choice by May 1, 2019. Your choice of 
whether or not to participate will not influence your future relations with Ryerson University or the researcher involved in the research.

\section{QUESTIONS ABOUT THE STUDY}

If you have any questions about the research now, please ask. If you have questions later about the research, you may contact:

Joey Violante, BSW

School of Social Work, Ryerson University

jviolant@ryerson.ca

Samantha Wehbi, MSW, PhD

School of Social Work, Faculty of Social Work at Ryerson University

swehbi@ryerson.ca

This study has been reviewed by the Ryerson University Research Ethics Board.

If you have questions regarding your rights as a participant in this study, please contact:

Research Ethics Board c/o Office of the Vice President,

Research and Innovation

Ryerson University

350 Victoria Street

Toronto, ON

M5B 2K3

416-979-5042

rebchair@,ryerson.ca

Project Title: People living in poverty with companion pets: Barriers to access and support

\section{CONFIRMATION OF AGREEMENT}

Your signature below indicates that you have read the information in this agreement and have had a chance to ask any questions you have about the study. Your signature also indicates that you agree to participate in the study and have been told that you can change your mind and withdraw your consent to participate at any time. You have been given a copy of this agreement. You have been told that by signing this consent agreement you are not giving up any of your legal rights. 
Name of Participant (please print)

Signature of Participant

Date

Participation in this study will include the use of audio recording. I agree to be audio-recorded for the purposes of this study. I understand how these recordings will be stored and destroyed. 


\section{Appendix B-Recruitment Flyer}

Ryerson

University

SCHOOL OF SOCIAL WORK

FACULTY OF COMMUNITY SERVICES

Ryerson REB Protocol Number 2019-009

\section{SEEKING RESEARCH PARTICIPANTS}

\section{People living in poverty with companion pets: Barriers to access and support}

Do you identify as a person living in poverty with a companion animal (a dog or cat)? Have you experienced homelessness or left a violent living situation with a pet?

What: up to a two hour interview talking about what your pet means to you, your experience of barriers in accessing social service supports (housing, shelter, mental health supports, harm reduction/addiction, hospital care and others) because of a lack of available options for care for your pet, and the decisions you had to make for yourself and your pet.

Where: Ryerson University or a mutually decided private location between participant and researcher (further details to be provided)

Who

Seeking participants who identify with the following:

- 18 years of age and up

- Living in the Greater Toronto Area

- Self-identification of either living in poverty, experiencing/ have experienced housing insecurity or homelessness, living in or exiting/have exited a violent living situation (in whatever way that is defined by you).

- Currently be in care of or have recently been in care of a pet (cat or dog) and accessed or wished to access social service supports such as housing, shelter, mental health supports, harm reduction/addiction, hospital care and others or be contact with social services systems involuntarily such as mental health systems and the criminal justice system.

- Participants will self-identify of having experienced barriers to access due to a pet or loss of a pet due to these barriers or systems.

Participants will receive a \$15 Tim Hortons gift card as a thank you for their time Two TTC tokens will be provided if required

Please contact: Joey Violante at jviolant@,ryerson.ca for more information

Participation is completely voluntary and if you choose not to participate it will not impact our relationship, or your relationship with Ryerson University.

This study has been approved by the Ryerson University Research Ethics Board and is being conducted by a graduate student in partial completion of a master of social work degree.

Research supervisor can be contacted at swehbi@ryerson.ca 


\section{Appendix C- Email Recruitment Script}

Ryerson

University

SCHOOL OF SOCIAL WORK

FACULTY OF COMMUNITY SERVICES

\section{Ryerson REB Protocol Number 2019-009}

Hello,

My name is Joey Violante I am a graduate student at Ryerson University in the School of Social Work. I am contacting you to see if you might be interested in participating in a research study. This research is being done as part of my Masters of Social Work project and my supervisor's name is Samantha Wehbi. The focus of the research is on people living in poverty with companion animals (cats and/or dogs).

To participate you need to be:

- 18 years of age and up

- Living in the Greater Toronto Area

- Self-identify as either living in poverty, experiencing/ have experienced housing insecurity or homelessness, living in or exiting/have exited a violent living situation (in whatever way that is defined by you).

- Currently be in care of or have recently been in care of a pet (cat and/or dog) and accessed or wished to access social service supports such as housing, shelter, mental health supports, harm reduction/addiction, hospital care and others or be contact with social services systems involuntarily such as mental health systems and the criminal justice system.

- Self-identify of having experienced barriers to access due to a pet or loss of a pet due to these barriers or systems.

If you agree to volunteer you will be asked to participate in a one-on-one audio recorded interview to talk about what your pet means/meant to you, your experience of barriers in accessing social service supports (housing, shelter, mental health supports, harm reduction/addiction, hospital care and others) because of a lack of available options for care for your pet, and the decisions you had to make for yourself and your pet.

Your participation will involve an up to two-hour one-on-one interview.

In appreciation of your time, you will receive a \$15 Tim Hortons gift card as well as TTC tokens (if needed) to attend our interview.

Your participation is completely voluntary and if you choose not to participate it will not impact our relationship, or your relationship with Ryerson University.

The research has been reviewed and approved by the Ryerson University Research Ethics Board. If you are interested in more information about the study or would like to volunteer, please contact me at jviolant@ryerson.ca.

Sincerely,

Joey Violante 


\title{
Appendix D-Interview guide
}

Ryerson

University

SCHOOL OF SOCIAL WORK

FACULTY OF COMMUNITY SERVICES

Ryerson REB Protocol Number 2019-009

\section{Interview Guide \\ People living in poverty with companion pets: Barriers to access and support}

\author{
Joey Violante \\ Interview Guide
}

\section{Introduction}

Affirm to participant that the recording can be stopped at any time or once recorded participant can ask for portions of the interview to not be included in the research. Participant can receive a copy of the transcript should they want to review for accuracy and make notes about portions they would not want included. The interview can be stopped as well at any time if participant would not like to continue. And any question can be skipped.

Let participant know that the questions are to guide our conversation, and they can go into as much or as little detail as they choose. If I have left out aspects of their story through the questions asked I would invite the participant to include what feels right and true for them.

\section{Opening /warm up questions}

Tell me a story about what your pet means/meant to you

\section{Interview Guiding Questions}

Can you tell me about a time you wanted or needed to do something that would affect your health or wellbeing but weren't able to because you couldn't bring your pet or had nobody to help you care for your pet

Can you tell me about a time you had to make a difficult choice between your health or wellbeing and your relationship with your pet (or where you didn't have control over a choice about your wellbeing or your pets)

Probing questions:

- Have you ever been placed in an unsafe situation (living situation or otherwise) because you worried about your pet/loosing your pet?

- What was the response from service providers about the barrier (i.e. social workers, etc.)

- What choices were you forced to make?

- Have you ever been told that you shouldn't have a pet?

- Have you ever had to give up your pet because you had no other choice? what was your relationship the pet? What was that experience like?

- Some people refer to their pet as a life line during lonely and/or difficult times, is this something that resonates with you?

- Can you tell me about a time you experienced discrimination when you asked for help?

- Do you have a relationship in your life that you would consider supportive? Do you consider your relationship with your pet supportive? 
- Do you feel that there are aspects of your identity (age, ethnicity, gender, etc.) that impact your experience?

Tell me about a time where your relationship with your pet was minimized?

What do you think would be helpful in reducing barriers? 


\section{Appendix E- Facebook Notice}

Ryerson

University

SCHOOL OF SOCIAL WORK

FACULTY OF COMMUNITY SERVICES

Ryerson REB Protocol Number 2019-009

\section{SEEKING RESEARCH PARTICIPANTS}

Do you identify as a person living in poverty with a companion animal (a dog or cat, either currently or previously)?

Have you experienced homelessness or left a violent living situation with a pet?

Would you be interested in sharing your experiences in a small research study?

My name is Joey Violante and I am a graduate student at Ryerson University in the School of Social Work. If you answered yes to some of the above questions and are interested in sharing your story in a one on one interview as part of a small research study please direct message me or email me at: jviolant@,ryerson.ca. Participants will receive a \$15 Tim Hortons gift card as a thank you for their time

Two TTC tokens will also be provided if needed

This research is being done as part of my Masters of Social Work project and my supervisor's name is Samantha Wehbi. The focus of the research is on people living in poverty with companion animals (cats and/or dogs).

What: up to a two hour interview talking about what your pet means/meant to you, your experience of barriers in accessing social service supports (housing, shelter, mental health supports, harm reduction/addiction, hospital care and others) because of a lack of available options for care for your pet, and the decisions you had to make for yourself and your pet.

Where: Ryerson University or a mutually decided private location between participant and researcher (further details to be provided)

Who

Seeking participants who identify with the following:

- 18 years of age and up

- Living in the Greater Toronto Area

- Self-identification of either living in poverty, experiencing/ have experienced housing insecurity or homelessness, living in or exiting/have exited a violent living situation (in whatever way that is defined by you).

- Currently be in care of or have recently been in care of a pet (cat or dog) and accessed or wished to access social service supports such as housing, shelter, mental health supports, harm reduction/addiction, hospital care and others or be contact with social services systems involuntarily such as mental health systems and the criminal justice system.

- Participants will self-identify of having experienced barriers to access due to a pet or loss of a pet due to these barriers or systems. 
Participation is completely voluntary and if you choose not to participate it will not impact our relationship, or your relationship with Ryerson University.

This study has been approved by the Ryerson University Research Ethics Board (Ryerson REB Protocol Number 2019-009) and is being conducted by a graduate student in partial completion of a master of social work degree. Research supervisor can be contacted at swehbi@ryerson.ca. 


\section{Appendix F-Research Ethics Board Approval Document}

\section{Ryerson Ethics Board \\ University \\ Research}

To: Joanna (Joey) Violante Social Work

Re: REB 2019-009: People Living in Poverty with Pets: Barriers to access and support Date: February 8, 2019

Dear Joanna (Joey) Violante,

The review of your protocol REB File REB 2019-009 is now complete. The project has been approved for a one year period. Please note that before proceeding with your project, compliance with other required University approvals/certifications, institutional requirements, or governmental authorizations may be required.

This approval may be extended after one year upon request. Please be advised that if the project is not renewed, approval will expire and no more research involving humans may take place. If this is a funded project, access to research funds may also be affected.

Please note that REB approval policies require that you adhere strictly to the protocol as last reviewed by the REB and that any modifications must be approved by the Board before they can be implemented. Adverse or unexpected events must be reported to the REB as soon as possible with an indication from the Principal Investigator as to how, in the view of the Principal Investigator, these events affect the continuation of the protocol.

Finally, if research subjects are in the care of a health facility, at a school, or other institution or community organization, it is the responsibility of the Principal Investigator to ensure that the ethical guidelines and approvals of those facilities or institutions are obtained and filed with the REB prior to the initiation of any research.

Please quote your REB file number (REB 2019-009) on future correspondence. Congratulations and best of luck in conducting your research.

Dr. Patrizia Albanese, PhD Chair, Ryerson University Research Ethics Board

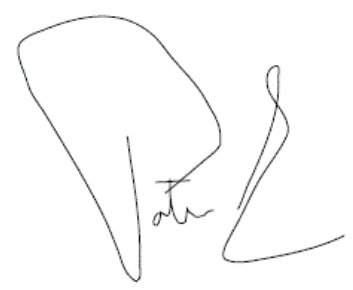

The Following protocol attachments have been reviewed and approved. 
Appendix Appendix Appendix Appendix Appendix 2019) Appendix Appendix Appendix Feb 2019) Comments to Chair February 8, 2019.docx (submitted on: 08 Feb 2019) Appendix ECommunity Resources February 8, 2019 Version 2.docx (submitted on: 08 Feb 2019)

C-Email Recruitment Script January 4, 2019.docx (submitted on: 04 Jan 2019) B-Recruitment Flyer January 4, 2019.docx (submitted on: 04 Jan 2019) D-Interview Guide January 4, 2019.docx (submitted on: 04 Jan 2019) E- Community Resources January 4, 2019.docx (submitted on: 04 Jan 2019)

F - Literature Review References January 4, 2019.docx (submitted on: 04 Jan

\section{$\bullet$}

A-Consent Form January 4, 2019.docx (submitted on: 04 Jan 2019) A-Consent Form February 8, 2019 Version 2.docx (submitted on: 08 Feb 2019) C-Email Recruitment Script February 8, 2019 Version 2.docx (submitted on: 08

\footnotetext{
Appendix D-Interview Guide February 8, 2019 Version 2.docx (submitted on: 08 Feb 2019) Appendix B-Recruitment Flyer February 8, 2019 Version 2.docx (submitted on: 08 Feb 2019)

If any changes are made to the attached document throughout the course of the research, an amendment MUST be submitted to, and subsequently approved by the REB.
} 


\section{REFERENCES}

Baines, D. (2011). An overview of anti-oppressive social work practice: Neoliberalism, inequality, and change In D. Baines (Ed.), Doing anti-oppressive practice: Social justice work (2nd ed., pp. 25-47). Black Point, NS: Fernwood Publishing.

Bonnycastle, C. (2006). From social equality to compassion,A critique of the 2005 CASW Code of Ethics. Canadian Social Work Review , 23 (2): 77-94.

http://ezproxy.lib.ryerson.ca/login?url=http://search.proquest.com/docview/210098836?accou $\underline{\text { ntid }=13631}$

Boyd, J., Cunningham, D., Anderson, S., \& Kerr, T. (2016) Supportive housing and surveillance. International Journal of Drug Policy, 34(1), $72-79$

Bullen, J. (2015). Governing homelessness: The discursive and institutional construction of homelessness in australia. Housing, Theory and Society, 32(2), 218-239. doi:10.1080/14036096.2015.1024886

Campbell, C. (2003). Introduction. What is anti-oppressive social work, and theory. In C. Campbell, Anti-oppressive social work. Promoting equity and social justice. Retrieved from: http://aosw.socialwork.dal.ca/index.html

Carter, S.M. \& Little, M. (2007) Justifying knowledge, justifying method, taking action: Epistemologies, methodologies and methods in qualitative research, Qualitative Health Research, 17(10), 1316-1328.

Chase, S. E. (2003). Learning to listen: Narrative principles in a qualitative research methods course. In R. Josselson, A. Lieblich; D. P. McAdams (Eds.) Up close and personal: The 
teaching and learning of narrative research (pp.79-99). Washington, DC: American Psychological Association.

Crenshaw, K. (1991). Mapping the Margins: Intersectionality, Identity Politics, and Violence against Women of Color. Stanford Law Review, 43(6), 1241-1299. doi:10.2307/1229039

Creswell, J.W. (2013). Five qualitative approaches to inquiry. In Qualitative inquiry and research design (3rd ed) (pp. 69-110). Los Angeles: SAGE.

Cronley, C., Strand, E. B. Patterson, D. A., \& Gwaltney, S. (2009) Homeless people who are animal caretakers: A comparative study. Psychological Reports, 481-499

Dockray, H. (2019, May 24). Self-care isn't enough. We need community care to thrive. Retrieved from https://mashable.com/article/community-care-versus-selfcare/?fbclid=IwAR0sZ9KyX2ugle1YvGrc23QQdewgB8Je0th516hB0potivH2yKpS_WYBzo

Donohue, K. M. (2005). Pet loss: Implications for social work practice. Social Work, 50(2), 187 90. Retrieved from http://ezproxy.lib.ryerson.ca/login?url=https://search-proquestcom.ezproxy.lib.ryerson.ca/docview/215269255?accountid=13631

Duffey, T. (2007). Saying goodbye. Journal of Creativity in Mental Health, 1(3-4), 287-295. doi:10.1300/J456v01n03_17Eisenchlas, S. A. (2013). Gender Roles and Expectations: Any Changes Online? SAGE Open. https://doi.org/10.1177/2158244013506446

Faver, C. A., \& Strand, E. B. (2003). To leave or to stay? battered women's concern for vulnerable pets. Journal of Interpersonal Violence, 18(12), 1367-1377. doi:http://dx.doi.org.ezproxy.lib.ryerson.ca/10.1177/0886260503258028 
Foucault, M., Senellart, M., \& Burchell, G. (2008). The birth of biopolitics : Lectures at the colle'ge de france, 1978-79. Retrieved from https://ebookcentral-proquestcom.ezproxy.lib.ryerson.ca

Fraser, H. (2004). Doing narrative research; Analyzing personal stories line by line. Qualitative Gill, A. (2018) Survivor-Centered Research: Towards an Intersectional Gender-Based Violence Movement, Journal of Family Violence, 33(8), 559-562 https://doiorg.ezproxy.lib.ryerson.ca/10.1007/s10896-018-9993-0

Gray, M., Plath, D. \& Webb, S. (2009). Framing social work. In Evidence-based social work: A critical stance. (pp. 51-75).

Hardesty, J., Khaw, L., Ridgway, M., Weber, C., \& Miles, T. (2013). Coercive control and abused Women's decisions about their pets when seeking shelter. Journal of Interpersonal Violence, 28(13), 2617-2639. doi:10.1177/0886260513487994

Healy, K. (2005). Social work theories in context: Creating frameworks for practice. Basingstoke: Palgrave Macmillan.Hollway, W., \& Jefferson, T. (2000). Doing qualitative research differently. London, : SAGE Publications Ltd doi: 10.4135/9781849209007

Howe, L., \& Easterbrook, M. J. (2018). The perceived costs and benefits of pet ownership for homeless people in the UK: Practical costs, psychological benefits and vulnerability. Journal of Poverty, 22(6), 486-499. doi:10.1080/10875549.2018.1460741

Hunter, M. (2002). Rethinking epistemology, methodology, and racism: or, is White sociology really dead? Race \& Society, 119-138.

Irvine, L. , Kahl, K. N. and Smith, J. M. (2012), CONFRONTATIONS AND DONATIONS: Encounters between Homeless Pet Owners and the Public. The Sociological Quarterly, 53: 
25-43. doi:10.1111/j.1533-8525.2011.01224.xIrvine, L. (2016). My dog always eats first: Homeless people and their animals. Boulder: Lynne Rienner.

Jeffery, D. (2007). RADICAL PROBLEMS AND LIBERAL SELVES: Professional subjectivity in the anti-oppressive social work classroom. Canadian Social Work Review, 24(2), 125-139. Retrieved from http://ezproxy.lib.ryerson.ca/login?url=https://search-proquestcom.ezproxy.lib.ryerson.ca/docview/210097913?accountid=13631

Kabel, A., Khosla, N., \& Teti, M. (2015). The dog narratives: Benefits of the Human-Animal bond for women with HIV. Journal of HIV/AIDS \& Social Services, 14(4), 405-416. doi:10.1080/15381501.2013.860069

Khosla, P.(2008). If low-income women of colour counted in Toronto. In M.A. Wallis and S. Kwok (Eds.), Daily Struggles: The Deepening Racialization and Feminization of Poverty in Canada(pp. 223-247). Toronto: Canadian Scholars' Press.

Labrecque,J., \& Walsh, C.A. (2011) Homeless women's voices on incorporating companion animals into shelter services, Anthrozoös, 24(1), 7995, DOI: $10.2752 / 175303711 X 12923300467447$

Lem, M., Coe, J. B., Haley, D. B., Stone, E., \& O'Grady, W. (2016). The protective association between pet ownership and depression among street-involved youth: A cross-sectional study. Anthrozoös, 29(1), 123-136. doi:10.1080/08927936.2015.1082772

Maiter, S., Simich, L., Jacobson, N., \& Wise, J. (2008). Reciprocity: An ethic for communitybased participatory action research. Action Research, 6(3), 305-325. https://doi.org/10.1177/1476750307083720

Meyer, M. H. (Ed.). (2000). Care work: Gender, labor, and the welfare state. Retrieved from https://ebookcentral-proquest-com.ezproxy.lib.ryerson.ca 
Moffatt, K. (1999). Surveillance and government of the welfare recipient. In A. Chambon, A. Irving, \& L. Epstein, Reading Foucault for Social Work, pp. 219-242. New York : Columbia University Press.

Nadasen, P. (2013). Domestic Work, Neoliberalism, and Transforming Labor. Retrieved May 10, 2019, from http://sfonline.barnard.edu/gender-justice-and-neoliberaltransformations/domestic-work-neoliberalism-and-transforming-labor/

Neuman, W.L. (2006). The meanings of methodology. In Social research methods: Quantitative and quantitative approaches (6th ed.), (pp. 79-104). Boston: Pearson Education Inc.

Risley-Curtiss, C. (2010). Social work practitioners and the Human—Companion animal bond: A national study. Social Work, 55(1), 38-46. doi:10.1093/sw/55.1.38

Slatter, J., Lloyd, C., \& King, R. (2012). Homelessness and Companion Animals: More than Just a Pet? British Journal of Occupational Therapy, 75(8), 377-383. https://doi.org/10.4276/030802212X13433105374350

Smith, K. (2017). A research design for the "Messy Actualities" of restructured social work. In H. Parada \& S. Wehbi (Eds). Reimagining anti-oppression social work research. (pp. 71-86). Toronto: Canadian Scholars. Social Work, 3(2), 179-201.

Walsh, F. (2009). Human-animal bonds I: The relational significance of companion animals. Family Process, 48(4), 462-480. doi:10.1111/j.1545-5300.2009.01296.x

Williams, F. (2018). Care: Intersections of scales, inequalities and crises. Current Sociology, 66(4), 547-561. https://doi.org/10.1177/0011392118765206

Yamasaki, J. (2018). The communicative role of companion pets in patient-centered critical care. Patient Education and Counseling, 101(5), 830-835. doi:10.1016/j.pec.2017.12.014 